This is the peer reviewed version of the following article: Kim Suk-Joong and Wu Eliza 2011, 'International bank flows to emerging markets: Influence of sovereign credit ratings and their regional spillover effects', Blackwell Publishing Ltd, vol. 34, no. 2, pp. 331-364. which has been published in final form at http://dx.doi.org/10.1111/j.14756803.2011.01293.x This article may be used for non-commercial purposes in accordance With Wiley Terms and Conditions for self-archiving' 


\title{
INTERNATIONAL BANK FLOWS TO EMERGING MARKETS: INFLUENCE OF SOVEREIGN CREDIT RATINGS AND THEIR REGIONAL SPILLOVER EFFECTS
}

\author{
Suk-Joong Kim \\ University of Sydney \\ Eliza $\mathrm{Wu}^{*}$ \\ University of Technology, Sydney
}

\begin{abstract}
We examine whether changes in sovereign credit assessments help to determine international bank flows to emerging countries. We focus on the banking flows of G7 countries to a sample of 55 emerging market borrowers for 1995-2008. We find evidence indicating that sovereign credit rating revisions have significant and positive influences on international bank flows from developed markets even after controlling for other determinants. In addition, we find strong regional rating spillover effects. Ratings improvements in one emerging market region tends to reduce bank flows to the other regions. However, there is an exception from the Asia Pacific to Eastern Europe.
\end{abstract}

JEL classification: E44, E65, F33, F34, G15

\footnotetext{
* We thank an anonymous referee, Gerald Gay and Jayant Kale (the Editors), Kee-Hong Bae, Iftekhar Hasan, David Parsley, Chu Zhang as well as seminar participants at various universities and conferences for constructive comments on earlier drafts of this article. All errors remain our own.
} 


\section{Introduction.}

International bank flows provide the necessary external financing for firms in emerging markets as these economies transition through stages of financial development. Banks in more developed countries have channeled significant funds to emerging market borrowers in recent years, creating a phenomenal risk exposure for the global banking system. Yet the importance of the banking sector for accelerating economic growth is widely recognized (Levine and Zervos 1998). Hence, a clearer understanding of the determinants of international banking activities in emerging markets is of global interest and crucial for supporting the financial and economic development of the world economy.

In the current literature assessing the determinants of cross-border banking claims (e.g., Herrero and Martinez-Peria 2007; Papaioannou 2009), the significant roles of geography and informational asymmetries, sound economic performance, banking sector development, institutional quality, and political stability have been investigated. However, despite their documented influence on various segments of financial markets (Kaminsky and Schmukler 1999; Kim and Wu 2008) and regulatory importance for bank capital adequacy assessment under the Basel II framework, the role of sovereign credit ratings in influencing international bank flows has not been previously examined. A timely assessment is needed in light of recent criticisms on rating agencies’ complicity in the subprime crisis.

Based on the theoretical work of Diamond (1984), it is well accepted that financial institutions play a crucial delegated monitoring role in financial intermediation. We find evidence in this study that in international bank lending this monitoring role is partially shared with rating agencies. Boot, Milbourne and Schmeits (2006) show that agency credit ratings are used as signals for financial decision making and credit rating agencies serve a monitoring role. Thus, in theory, credit rating assessments should reduce the information generation efforts and information asymmetry faced by international banks, making them more inclined 
to enter into loan contracts with borrowers in emerging markets. This could work either directly through sovereign ratings' information content on banks' local country risks or indirectly through an implicit sovereign ceiling for all the credits of a country (see Durbin and Ng 2006). In support of the informational value of credit ratings, Merrill Lynch (1999) purports that credit rating agencies can help lenders to "pierce the fog" of asymmetric information that surrounds lending relationships. In related lines of inquiry, previous studies such as Yi and Mullineaux (2006) find that syndicated bank loan ratings are informative for financial market participants, and Kim and Wu (2008) find emerging countries with better sovereign ratings were associated with more developed banking sectors.

In this article, we examine whether sovereign credit rating assessments have informational value for cross-border bank lending decisions. It is well accepted that sovereign credit rating assessments provided by rating agencies are based on fundamental aspects of a country’s debt history and macroeconomic performance (Cantor and Packer 1996). Hence, sovereign credit ratings are used as reference measures for individual country's creditworthiness. In recognizing this, much of the literature on sovereign credit ratings focuses on their short-term information content for financial market returns and linkages (see, e.g., Kaminsky and Schmukler 1999; Brooks et al. 2004). However, it is also understood that there are many other factors simultaneously influencing a country’s debt repayment ability including political and other expropriation risks, exchange rate volatility, and currency controls and legal and institutional quality (Butler and Fauver 2006). This comprehensive assessment makes sovereign credit ratings a vital determinant of international bank lending to emerging markets. We examine this issue by focusing on the quarterly changes in bank claims of G7 countries on an extensive sample of 55 emerging markets and use Standard \& Poor's (S\&P) sovereign credit rating assessments from Q1:1995 - Q4:2008. ${ }^{1}$

\footnotetext{
${ }^{1}$ In addition to S\&P we also considered the ratings measures produced by other rating agencies like Moodys and Fitch Ratings. However, we opted to use the S\&P measures as they cover a larger number of sovereigns and are
} 
We find strong evidence indicating that sovereign credit rating revisions and, to a lesser extent, outlook changes have significant positive influences on international bank flows from developed markets - even after controlling for the potential influences of various proxies for informational asymmetries, financial and economic development, openness, and governance quality in an extended gravity model specification. Specifically, sovereign rating revisions on foreign-currency-denominated debt is more influential for bank flows to investment-grade borrowers, whereas lending decisions to non-investment-grade countries appear to be swayed more by revisions on local currency ratings as the latter is designed to reflect a country's fundamental prospects and the former reflects the sovereign obligor's ability to repay debt in hard currencies. Furthermore, our results suggest that geographical proximity and cultural and legal linkages are only important for ameliorating informational asymmetries in more risky lending decisions to borrowers from non-investment-grade countries. International lenders have a clear preference for targeting riskier emerging markets that are closer to their borders and share their own cultural and legal backgrounds. In addition, they tend to orientate their non-investment-grade lending toward countries with lower governance quality and tighter foreign exchange controls. The reverse is true of bank flows to investment-grade countries.

Finally, we report significant competitive rating spillover effects, with G7’s bank flows to emerging markets declining in response to improvements in credit conditions of other emerging market regions. However, there is some evidence that currency rating spillover effects are more heterogeneous before 2004 when rating improvements in Asia and Eastern Europe significantly lifted the bank flows to other emerging market regions. Taken together, sovereign credit ratings have unequivocal informational value for international bank lenders.

re-rated more frequently. Furthermore, the literature reports that the sovereign credit ratings provided by S\&P generally leads that of the other agencies and hence, have greater market impacts (see, e.g., Brooks et al. 2004; Gande and Parsley 2005). 
In spite of the large volume of studies on international banking, our study is to the best of our knowledge the first to explicitly analyze the impact of agency ratings ${ }^{2}$ and their spillover effects on the flow of those banking claims. The more traditional strand of the sovereign ratings literature examines the role of sovereign rating revisions during major episodes of financial market contagion (Kaminsky and Schmukler 2002; Chiang, Jeon, and $\mathrm{Li}$ 2007), and it remains a concern whether sovereign rating changes are procyclical and exacerbate cross-market comovements during times of financial crises. Nonetheless, it is recognized in a relatively newer strand of the sovereign ratings literature that sovereign rating changes for individual countries have significant informational spillover effects across other international debt and equity markets (Gande and Parsley 2005; Ferreira and Gama 2007). It is this latter strand of the literature that we follow in our rating spillover analysis, as it is more appropriate for understanding the wide-reaching effects on international bank flows that are available at a much lower frequency than for financial returns and their short-term correlations.

There are important implications in this research for financial institutions management, international portfolio choice and international banking regulations. Our study contributes a much-needed new perspective on international banking under the Basel II regulatory framework for assessing bank risks, whereby sovereign credit ratings have been introduced as a gauge for banks’ lending activities (ultimately their risky assets). Our results have clear policy implications for future reforms to strengthen the international financial architecture as they suggest the role of sovereign ratings should be maintained in financial risk assessments in emerging markets where there are greater informational asymmetries in cross-border lending decisions. Furthermore, our findings suggest that public debt

\footnotetext{
${ }^{2}$ Although International Country Risk Guide (ICRG) indicators are used by Papaioannou (2009) and Herrero and Martinez-Peria (2007), among a host of other determinants, sovereign credit ratings provided by rating agencies have never been explored to our best knowledge.
} 
management strongly affects banking sector financing in emerging markets and can significantly help encourage the flow of funds from rich to poor countries.

\section{Data Descriptions}

\section{Sovereign Ratings}

We study a sample of 55 emerging market countries from four key geographical regions -Asia-Pacific (AP), Latin America (LA), Africa/Middle East (AME) and Emerging Europe (EE) rated by S\&P from Q1:1995 to Q4:2008 (see Table A1 in Appendix A for our country list). The sovereign credit rating assessments provided by S\&P includes long-term sovereign credit ratings and associated outlooks and credit watches for both foreign-currencyand local-currency-denominated sovereign debt. ${ }^{3}$ The highest rating on the S\&P rating scale is AAA and the lowest is D/SD (default or selective default) and the ratings are published with ratings outlooks ranging from Credit Watch-Positive to Credit Watch-Negative. The investment grade ratings are $\mathrm{BBB}$ - and above and the ratings $\mathrm{BB}^{+}$and below are noninvestment grade. Whilst ratings are reviewed regularly by rating agencies, re-ratings are made only in exceptional circumstances when the agencies perceive a permanent fundamental change in a country's credit quality. Specifically, rating guidance is either in the form of a change in the ratings or issue of outlooks and credit watches with the former indicating an actual change in the perceived credit quality of a sovereign obligor and the latter indicating a potential rating change in the near term.

In order to facilitate empirical analyses, the S\&P sovereign ratings and outlooks/credit watches are linearly transformed following Cantor and Packer (1996) and Gande and Parsley (2005) into separate (quarterly) time series for each of the sample countries in two steps. First,

\footnotetext{
${ }^{3}$ Although ratings on short-term sovereign debt are available and are examined in prior studies, we do not examine their effects in this study as international bank lending is dominated by maturities of two years or more. A focused assessment on long-term rating impacts reduces potential maturity mismatch in our analyses.
} 
we allocate numerical values for each of the rating grades which vary from 20 for AAA and 0 for default and selected default. We then investigate the roles of the long-term ratings and intermediate outlooks separately for the purpose of explaining the G7 bank flows to the 55 emerging market economies. Hence, we begin by generating four daily time series for each sample country based on the ratings and outlooks on their foreign- and local-currencydenominated debt. We assign the announced rating and outlook values to and from the days of rating revisions until the date of the next rating event. For example, S\&P changed the longterm foreign currency rating of Brazil from $\mathrm{BB}$ with positive outlook to $\mathrm{BB}+$ with positive outlook on 16 May 2007, and then to BBB- on 30 April 2008. We allocate 10 (the numeric value assigned to $\mathrm{BB}+$ ) for the days between 16 May 2007 and 29 April 2008, and 11 (the value for BBB-) for 30 April 2008 and beyond. The quarterly ratings are then generated by averaging daily ratings for each quarter. The outlook series are generated in a similar fashion. Secondly, consistent with the literature, we use an aggregate (comprehensive) measure of the linearly transformed ratings and outlooks to investigate the potential of inter-regional ratings information spillover effects in bank flows to emerging markets. The extant literature documents significant ratings spillover effects in international debt and stock markets (Gande and Parsley 2005; Ferreira and Gama 2007, respectively). Our study thus significantly adds to this literature by providing new results on credit rating spillover effects at the regional level and for cross-border bank flows. We generate the comprehensive credit ratings measure for our regional spillover analyses by adjusting each rating score with its associated outlook value over time. For example, the rating score of CC with negative outlook will be allocated an aggregate score of 0.75 (1, which is the score of CC rating, minus 0.25 , which is the score for a negative outlook). 


\section{G7 Bank Flow Variables}

We investigate the role of sovereign ratings on the bank flows from G7 countries' lending banks to a group of 55 emerging market countries. We rely on the most comprehensive source of international banking data that is currently available and that is provided by the Bank for International Settlements (BIS) in their Consolidated Banking Statistics dataset. The BIS collects data on foreign claims extended by international banks from more than 20 developed BIS-reporting countries. These on-balance sheet claims cover not only direct bank loans extended from bank headquarters but also by bank branches and subsidiaries in foreign markets as well as banks' holdings of debt securities and other assets. However, we focus specifically on G7 countries due to their dominance in international bank lending to emerging markets. The banking flow data used are the quarterly changes in the G7 banks' foreign claims on each of our 55 target emerging markets as reported in the BIS's consolidated banking statistics (Table 9B: Consolidated foreign claims of reporting banks immediate borrower basis). ${ }^{4}$ In using this data, we can accurately capture the risk exposures of G7 national banking systems to our wide sample of emerging markets.

\section{Control Variables}

We narrow the list of potential explanatory variables by firstly considering those control variables that would be of direct relevance to international bank flows as suggested by the existing literature and would not be collinear with our rating and outlook variables. Our

\footnotetext{
${ }^{4}$ In addition, the BIS reports foreign banking claims in ultimate risk basis (Table 9D), which includes data on some off-balance sheet exposures of domestic banks. However, this database currently omits Germany, one of the more important G7 countries and so we opt to not use this dataset for our investigation. However, as a robustness check, we also re-estimate our models for the remaining six major developed countries using the alternative database on foreign claims on ultimate borrower basis. The estimation results are qualitatively the same for both measures of foreign bank claims.
} 
control variables can be broadly categorized into four groups - bilateral linkages, financial and economic development, financial openness and governance standards.

Bilateral Linkages. We first account for informational control variables that are customarily used in cross-border banking studies. These should help to reduce model misspecification errors from the omission of important variables. To minimize problems with multicollinearity, we also examine correlations between individual control variables (which are not unreasonably high). The details on all variables used are provided in Table B1 in Appendix B.

The literature on international bank flows borrows from the international trade literature a "gravity model” which essentially addresses various measures of linkages between target and donor countries (see, e.g., Buch 2005). According to these types of models, bilateral trade or capital flows between two countries is inversely related to geographical distance as in the case of lending, the further away is a borrower, the more difficult it becomes for the lender to monitor and gather information to assess credit risks. Variables which capture trade restrictions and other information costs (asymmetries) are usually also added. These include cultural and legal linkages and also economic linkages such as total trade flows between the pair. There is much empirical evidence within international finance to support the idea that these proxies for information asymmetry (or familiarity) significantly influence cross-border exchanges of financial assets (Portes and Rey 2005) or affect economic outcomes and financial activities (Guiso, Sapienza, and Zingales 2006; La Porta et al. 1997). We anticipate that G7 lenders based in countries sharing a similar cultural background or legal environment with a borrower may have less of an informational disadvantage in their lending decisions. Hence, we include variables to capture bilateral geographical, economical, political and cultural linkages in the spirit of these gravity models. 
First, we employ a geographical distance (DIST) measure between a donor (G7) and a target (emerging market) country measured in (natural log) kilometers to control for geographical proximity. ${ }^{5}$ Second, is the total value of merchandise trade in natural logs (TOTTRADE) between each country pair calculated in both directions (sum of import from and export to each of the 55 emerging countries from the viewpoint of G7 countries). Third, we use the amount of official aid flows donated (DON) from each G7 country to a target emerging market as a proxy for the political ties between the rich and poor nations. It is conceivable that bilateral political ties may flow down to influence a country's bank lending program. There is sufficient evidence to suggest that political connections are associated with preferential access to contractual based debt financing within many developing countries (see Faccio, Masulis, and McConnell 2006 and references therein). The political dimension of bilateral linkages has not previously been investigated in studies on cross-border financial flows but we argue is worth considering. It is likely that international bank lenders would factor into their lending decisions their own government's political and economic support for a political ally as they may at the very least, feel more comfortable with extending credit to these markets if not count on an implicit guarantee from their own government. Lastly, we consider several cultural linkage dummies between each of the 55 emerging market countries with G7 countries. There are four dummy variables that take the value of one if there is a shared link between an emerging country and one of the G7 countries and zero otherwise. We consider 1) English as a business or official language (Stulz and Williamson 2003), 2) Membership of the European Union, 3) Use of a Common Law legal framework and 4) Civil Law legal origin (La Porta et al. 1997).

\footnotetext{
${ }^{5}$ The geographical distance between two countries (a donor country and a recipient country) can be accurately measured using the great circle distance formula which is given below (in kilometers):

Distance $_{\mathrm{ij}}=\operatorname{ArcCos}\left(\operatorname{Sin}\left(\mathrm{Lat}_{\mathrm{i}}\right) \times \operatorname{Sin}\left(\mathrm{Lat}_{\mathrm{j}}\right)+\operatorname{Cos}\left(\mathrm{Lat}_{\mathrm{i}}\right) \times \operatorname{Cos}\left(\mathrm{Lat}_{\mathrm{j}}\right) \times \operatorname{Cos}\left(\operatorname{Long}_{\mathrm{j}}-\operatorname{Long}_{\mathrm{i}}\right) \times 6371\right.$,

where Lat and Long are the latitude and longitude of the capital city of each country,pair and the subscripts $i$ and $j$ denote the two countries in each pair-wise calculation. A similar approach has been adopted in prior work by Coval and Moskowitz (1999).
} 


\section{Financial and Economic Development}

In this category, we employ several measures for financial and economic development. In traditional gravity model specifications, the size of the target country's economy (or population) is typically included as a determinant as it is thought that larger economies would exert greater pulling power for trade or bank flows. Hence, we include log GDP (LGDP) as a measure of economic development (Herrero and Martinez-Peria 2007). Consistent with the literature on financial development we also use stock market capitalization in natural logs (SMCAP) as a measure on a non-bank source of finance and the extent of financial market development (Rajan and Zingales 2003). Moreover, we control for stock market performance in the target country’s emerging market region (RSINDEXCH). ${ }^{6}$ Furthermore, we employ domestic credit provided by the banking sector in natural logs (BANKCRED) as a proxy for the size and development of the banking sector in each target country (Levine and Zervos 1998). We then employ two measures of banking sector efficiency and stability, interest rate spread (INTSPREAD) (i.e. difference between lending and deposit rates) and the ratio of liquid reserves to total assets (LIQTOASSET) respectively (see Claessens and Laeven 2004 and references therein).

\section{$\underline{\text { Financial Openness }}$}

We also include measures of international capital flows that may compete with bank flows - foreign direct investments (FDI) and portfolio investment inflows (PORTFOLIO) both in natural logs (Bekaert and Wang 2009). The effect of these alternative forms of capital flows are uncertain a priori as they could either present competitive effects on international bank financing or more generally indicate a greater degree of financial openness in target

\footnotetext{
${ }^{6}$ We omit reporting the regression results with national stock market returns as comparable stock market indices for our entire sample period are available for less than half of our emerging market sample. However, subsample regression results for national stock market returns are available upon request.
} 
countries (Bekaert and Wang 2009). Hence, we also include two alternative measures of investment restrictions - on direct investments (DBARR) and financial credits (FBARR). We also control for foreign exchange regulations that may hinder capital flows. Countries in our sample exercised a wide spectrum of exchange rate and monetary policy arrangements that have different degrees of controls of international capital flows. For example, countries that have dollarized their currencies and the ones with a currency board arrangement would experience a lower degree of capital flows than countries that have a floating exchange rate system. We control for this by introducing a foreign exchange regime indicator variable, FXREGM, with values ranging from 0 to $4(0=$ floating systems, $1=$ crawling pegs, $2=$ pegs to one or more currencies, 3 = currency board system, and 4 = dollarization).

\section{$\underline{\text { Governance Quality }}$}

Finally, we control in aggregate for various governance issues that may arise during the process of financial development and impact upon international capital flows. We employ the World Bank governance indicators which are designed to measure six dimensions of governance: voice and accountability, political stability, government effectiveness, regulation quality, rule of law and control of corruption. In these series, a higher value is indicative of better governance in that particular dimension. The details of the construction of these measures are to be found in Kauffman, Kraay, and Mastruzzi 2009. This is one of the most comprehensive compilations of data on governance across time and countries currently available. Following Butler and Fauver (2006), we sum the six separate dimensions into a composite measure to represent a country’s overall governance and institutional quality. 


\section{Empirical model}

\section{Overall Impact of Sovereign Ratings Information}

We start with an overall panel data estimation of the G7 bank flows where the influence of the long-term sovereign ratings and outlooks for both foreign- and localcurrency-denominated debt are investigated (separately). ${ }^{7}$ The extended gravity model specification in equation (1) is estimated with random effects as fixed effects estimation is inappropriate in cases where some of the regressors (for example, the distance and cultural linkage measures) are time invariant.

G7BankFlows $s_{i, t}^{j}$

$$
\begin{aligned}
& =\alpha+\beta_{1} \cdot \Delta C R_{i, t-1}+\beta_{2} \cdot \Delta \text { Outlook }_{i, t-1}+\sum_{k=3}^{p} \beta_{k} \cdot \text { Bilateral_links } s_{i, t}^{k} \\
& +\sum_{k=10}^{q} \beta_{k} \cdot \text { Fin_devmt }_{i, t}^{k}+\sum_{k=16}^{r} \beta_{k} \cdot \text { Fin_open }_{i, t}^{k}+\beta_{20} \cdot \text { Gov }_{i, t}
\end{aligned}
$$

G7BankFlows are the quarterly changes in foreign claims of G7 countries' banks ( $j=$ Canada, France, Germany, Italy, Japan, U.K. and U.S.) against each of the 55 emerging market countries ( $i=1$ to 55) from Q1:1995 to Q4:2008. $\Delta C R_{i, t-1}$ and $\Delta$ Outlook $_{i, t-1}$ are last quarter's changes in long-term sovereign ratings and rating outlooks on foreign- and local-currencydenominated sovereign debt respectively. Local and foreign currency ratings and outlooks are estimated separately in Eq. (1). Bilateral_links is the set of bilateral linkage variables for geographical, trade, political and cultural ties between the G7 country and each target emerging market. Fin_devmt is the set of proxies for the level of financial and economic development in each emerging market (log GDP, stock market capitalization, domestic bank

\footnotetext{
${ }^{7}$ In our application, endogeneity is not an issue for two reasons. First, in most cases, ratings changed less frequently than the bank flows. As such if rating events are not concentrated around the end of each quarter, our changes in rating variables precede the dependent variable in the same quarter anyway. On top of this, we use the rating changes from the past quarter. Thus, we argue that our rating variables in the model are exogenous to the bank flows. Therefore, endogeneity of our ratings variable is less of a concern in our estimations.
} 
lending, interest rate spread, liquidity ratio of bank assets and stock market performance). Fin_open is the set of variables capturing the degree of financial openness in target emerging markets (FDI, portfolio investment inflows, direct investment barriers, financial barriers and foreign exchange controls). Lastly, Gov is Butler and Fauver's (2006) composite measure for governance quality covering the six dimensions of accountability, political stability, government effectiveness, regulation quality, rule of law and corruption assessed by the World Bank’s governance indicators (in Kaufman, Kraay, and Mastruzzi 2009).

We anticipate that, in general, the sovereign credit rating variables (for both local and foreign currencies) should have a significant positive influence on the G7 bank flows (i.e. positive coefficients on rating-based variables). This is because of the important leadership role governments play in the early stages of market development in many emerging market countries. In some circumstances, governments’ fiscal positions (debt repayment ability) can play a crucial role in providing various financial and non-financial safety nets to companies that are considered to be of some national significance (e.g., utility or national resource companies) even if the sovereign ceiling does not always hold in emerging markets (Durbin and $\mathrm{Ng}$ 2006). As such, improvements in sovereign governments' fiscal positions (as evidenced by improvements in ratings guidance) can be expected to have a positive effect on the G7 bank flows to those countries.

Emerging markets typically suffer from 'original sin' and are forced to borrow in international currencies like the US dollar and Euros for financing their domestic activities. As such, sovereign credit ratings on foreign currency debt primarily capture the perceived ability of a sovereign obligor to service its financial obligations in hard currencies. On the other hand, local currency credit ratings are a better reflection of inflationary risks and the fundamental health of the local economy as governments can generally increase taxes to avoid a debt default or monetize their national debt, leading to inflationary pressures. 


\section{Comparison of Investment and Non-Investment-Grade Ratings}

We also investigate the possibility that different rating grades may have differential impacts on international bank flows. The patterns of bank flows could be markedly different depending on whether the sovereign of the borrower country has an investment grade rating or not as there are often references in financial regulations that establish a specific use of credit ratings. For example, some financial institutions may face binding exposure limits on non-investment grade assets. Another reason could be that national governments often act as a lender of last resort and the ones with investment grade ratings are seen to provide better implicit protection for their domestic borrowers. ${ }^{8}$ Hence, we also estimate equation (1) separately for the two categories of countries - those with investment grade ratings (BBB- or the assigned numerical value of 10 and above) based on foreign then local currency ratings and those of non-investment grade sovereigns $(\mathrm{BB}+$ or the assigned numerical value of nine and below) in each quarter.

\section{Regional Spillover Effects of Ratings}

In addition to the above investigation of the overall influence of ratings and outlooks on bank flows, it is also important to examine potential spillover impacts of ratings information across emerging market regions. The G7 bank flows to an emerging market may depend not only on the target country's own ratings but also on the ratings of other emerging market regions. There is the potential of a 'crowding out effect' in bank loans to emerging markets. That is, if lending banks have allocated a fixed proportion of their loan portfolios to emerging market regions as a whole then an increase in bank flows to one region (due to a rating revision) would crowd out the flows into other regions. Alternatively, an increase

\footnotetext{
${ }^{8}$ However, countries that have dollarized or have a very strong form of a currency peg (e.g., a currency board) may lack this capability. In our sample, countries belonging to the former are Ecuador, El Salvador and Panama, and the countries for the latter include Bulgaria, Estonia, Hong Kong and Lithuania.
} 
(decrease) in bank flows to one region may coincide with similar increases (decreases) in other regions if an overall increase (decrease) in the credit allocation to emerging market borrowers is the source of the rise. For example, during the various episodes of financial crises in the late 1990s, emerging markets as a group experienced net international banking outflows (a total reduction of BIS reporting banks' claims to the tune of US\$247.3 billion over 1998-1999). However, the net banking inflows that started to emerge towards the end of 2002 were more region-specific with the emerging European countries receiving relatively more inflows than other emerging market regions. This was reversed in the fourth quarter of 2008 (due to the global financial crisis) where all four regions experienced significant net outflows (a total of US\$282 billion or $-10 \%$ ) and this was concentrated in the Asia Pacific region (US\$159 billion or $-18 \%$ ). In order to investigate the potential of rating spillover effects in cross-border bank flows, we model this as in equation (2) below.

$$
\begin{aligned}
& \text { G7BankFlows }_{i, t}^{j} \\
& =\alpha+\beta_{1} \cdot \Delta C R_{i, t-1}+\beta_{2} \cdot \Delta \text { Outlook }_{i, t-1} \\
& +\beta_{3} \cdot \Delta C R \_ \text {Spillover_ } 1_{t-1}+\beta_{4} \cdot \Delta C R_{-} \text {Spillover_ } 2_{t-1} \\
& +\beta_{5} \cdot \Delta C R_{-} \text {Spillover_3 }{ }_{t-1}+\beta_{6} \cdot \text { Principal_Component }
\end{aligned}
$$

The dependent variable, G7BankFlows $s_{k, t}^{j}$, is the quarterly bank flows of each of G7 country (j)'s banks to a regional (AP, LA, AME and EE) group of target countries (i). G7 bank flows to individual countries in a region are firstly explained by the target's own last quarter change in long-term credit ratings $\left(\Delta C R_{i, t-1}\right)$ and outlooks $\left(\Delta\right.$ Outlook $\left._{i, t-1}\right)$. We implement separate spillover estimations for foreign currency and local currency credit ratings and outlooks. Secondly, for each regional group we investigate the spillover effects of changes in the other three regions' comprehensive (aggregate) ratings (long-term credit rating adjusted for outlooks) with the variables, $\Delta C R \_$Spillover_1, $\Delta C R \_$Spillover_2 and $\triangle C R \_$Spillover_3. The three spillover variables are different for each of the four regional 
group estimations. Thirdly, we use the first principal component of all the control variables that are used in equation (1) (Principal_Component) to avoid model misspecification errors whilst keeping our spillover regressions parsimonious and the reporting of results manageable. Unlike Gande and Parsley (2005) whose focus is to investigate the impact of ratings events of one country on the sovereign credit spreads of others via an event study methodology, we focus on the longer term impact of ratings spillover effects on banking flows using a quarterly data frequency.

A negative coefficient for the spillover variables ( $\triangle C R \_$Spillover_1, $\Delta C R \_$Spillover_2 and $\Delta C R \_$Spillover_3) would suggest the bank flows into one region are crowding out the flows into others. That is, an improvement in the ratings of one region would increase the G7 bank flows into that region at the expense of the others. On the other hand, a positive coefficient indicates that a rating improvement in one region leads to more bank lending not only to that region itself but also to other emerging market regions. This is the case if the bank flows into one region might be part of an overall trend of the international bank flows to all emerging market countries.

\section{Empirical Results}

\section{Effects of Ratings Information on Bank Flows to Emerging Markets}

The full sample results for the overall bank flows model (Eq. 1) are shown in Table $1 .{ }^{9}$ The main variables of interest in this study - the rating and outlook variables $\left(\Delta C R_{i, t-1}\right.$ and $\Delta$ Outlook $_{i, t-1}$ ) - have the expected positive sign in all G7 country estimations except for the UK where ratings information are negative but insignificant. Ratings information also does not seem to significantly affect bank lending from Canada to emerging markets. Thus there is

\footnotetext{
${ }^{9}$ We also conduct robustness estimations where contemporaneous ratings changes are used instead of lags and the first principal component of the economic controls is used instead of using them individually. The ratings and outlook coefficients resulting from these estimations are qualitatively the same as what we report in this article. For the sake of brevity we are not reporting these robustness estimation results.
} 
sufficient evidence to suggest that improvements in sovereign credit ratings in both local- and foreign-currency-denominated borrowings help to encourage international bank flows from developed to emerging market economies. Rating assessments are particularly important for international lending from bank-based systems (France, Germany, Italy and Japan) compared to market based ones (US only). Whilst rating assessments on local-currency-denominated sovereign debt are slightly less significant than those on foreign-currency-denominated debt that are statistically significant at the $1 \%$ level for lending from France, Germany and the US and $5 \%$ for Japan and 10\% for Italy, both types of ratings have strong economic significance. A single notch improvement in foreign (local) currency credit ratings can increase bank financing to emerging markets in the subsequent quarter to the tune of US\$470 (307) million from France, US\$720 (308) million from Germany, US\$184 (165) million from Italy, US\$812 (823) million from Japan and US\$901 (568) million from the US respectively.

\section{[INSERT TABLE 1 HERE]}

The coefficients for the outlook changes are positive in all cases except for Italy but outlook and credit watch guidance have only incremental informational value over ratings for German and the U.S. banks. This is not surprising given that outlooks provide short term guidance on imminent rating changes over the next few months meaning that outlook revisions in the last quarter would have little informational value for lending decisions in the current quarter as it would be clear by then whether the outlook alert materialized into an actual rating change or not. Interestingly, the size of outlook coefficients are much larger compared to those for ratings suggesting that the economic effects of short-term ratings information is much greater (US\$2.6 and US\$2.2 billion respectively for foreign and local currency outlooks for German banks, and for the U.S. banks US\$3.5 and US\$3.4 billion, respectively). Importantly, the significance of ratings information remained strong even after 
controlling for various sources of bilateral linkages, extent of economic and financial development and openness and governance quality.

In our full sample results, we do not find that strong bilateral linkages necessarily promote institutional lending to all emerging markets. Whilst political and some cultural ties significantly encourage G7 banks to lend to emerging markets, geographical and trade links do not. First, we find mixed influence of geographical distance in international bank flows to emerging markets. It is only for Germany, that we find a significant negative link which is consistent with the cross-border financial flow literature (Portes and Rey 2005; Buch 2005). In other cases we find a positive relationship for Canada, France, Japan and the U.S. suggesting that bank lenders in these technologically advanced countries are not overly concerned with geographical proximity to all their borrowers. We hazard a guess that the banks from these countries may have concentrated on servicing their respective country's multinational clients in target emerging markets, and hence, distance may not have been a factor in their lending decisions.

Also in contrast to the existing evidence showing that closer trading ties promote cross-border financial flows, we also find a pervasive negative relationship between total trade and bank flows suggesting that trade activities may effectively provide non-bank sources of funds to emerging markets allowing them to be less reliant on international bank financing.

We contribute a new dimension to the international portfolio choice literature on the importance of bilateral political ties to international banking decisions. The estimated coefficients on DON are positive and significant for five of the G7 countries with the two exceptions being Italy and Japan with significantly negative coefficients. This result suggests that there may be implicit top down influences from a G7 government to its own banks to help out politically preferred emerging markets. This adds new international evidence to the 
literature documenting preferential access to financing from political connections within national financial systems (see, Faccio, Masulis, and McConnell 2006).

As for cultural and legal connections, the results are mixed for our full sample. Nonetheless, the result on shared membership in the European Union (EU) is stark. Whilst France, Germany and Italy exhibit strong lending preferences for emerging European markets that are also in the EU, UK banks tend to reduce their lending to these borrowers consistent with their overall stance on the ideals, practicalities and ultimately future success of European integration.

In general, the impacts of the economic control variables are by and large intuitive though not necessarily expected. We find that more G7 bank flows gravitate towards smaller economies (as measured by log GDP) and more efficient banking sectors (higher liquid asset ratios and lower interest rate spreads). This is potentially due to a substitution effect in banking and equity financing. The results reveal that larger (SMCAP) stock markets in more developed emerging market borrowers mostly discourage bank flows from G7 banks. Intuitively, emerging markets with larger and more developed stock markets would be less reliant on international bank financing. However, emerging countries with better performing (RSINDEXCH) stock markets (and overall economic development) attract more international banking flows. There are also some mixed signs on BANKCRED as it may be the case that emerging markets with more developed domestic banking sectors would be less reliant on international bank flows from abroad to satisfy local financing demands. Moreover, the relatively high correlation of 0.53 between BANKCRED and SMCAP suggests that emerging countries with larger domestic banking sectors are also equipped with more developed stock markets that can further alleviate the need for international bank financing.

On measures of financial openness, we also find evidence of other forms of international capital flows crowding out G7 bank lending as shown by significantly negative 
influences of both FDI and to a lesser extent debt and equity portfolio inflows (PORTFOLIO). Whilst significant, direct and financial investment restrictions (DBARR and FBARR) in target emerging markets do not pose a major hindrance on G7 lending to these destinations on average. In fact, our results suggest that investment restrictions on direct investments and financial credits work to increase demands for international bank financing as the alternative sources of funding are clamped down. As for the foreign exchange controls, in 5 out of 7 cases, the coefficient for FXREGM is negative which suggests that the more severe the control is the lower is the incoming bank flow. The negative coefficient is significant for France, Japan and the UK. However, a significant and positive coefficient is found for Italy and the U.S. This suggests that overall the Italian and the U.S. banks prefer the monetary policy discipline that tighter exchange controls bring in target borrower countries.

Lastly, we find that international bank flows are fairly sensitive to the governance and institutional environment in emerging markets. The composite governance index had a mixed influence on international bank flows. The positive coefficients for France and UK lending suggests that banks in these countries place great importance on overall governance quality and they are more inclined to increase their lending to better governed emerging markets. However, for other G7 countries the overall governance quality of emerging markets was either insignificant or inversely related to their bank lending. This may suggest that an improvement in the aggregate governance index reduces emerging markets' reliance on international bank financing as alternative forms of international financial flows become more accessible as investor protection improves. Alternatively, as Bae and Goyal (2009) find that banks on average charge higher loan spreads in countries with lower legal rights and enforcement, banks in some G7 countries may in practice have a profit motive to reduce their lending to emerging markets as governance quality improves. 
Investment-Grade Vs. Non-Investment-Grade Rating Effects

We next check for potential differences in the effect of sovereign credit ratings as well as other determinants on international bank flows going towards investment-grade versus speculative-grade borrowers in emerging markets. Given some financial institutions may have an incentive if not a mandate to avoid lending activities in the non-investment grade spectrum, it is important to test for demarcation effects in the relationship between sovereign ratings and international bank lending.

A comparison of results for bank flows entering into investment- and non-investmentgrade destinations is provided in Table 2. We summarize three salient points of the estimations. First, we observe that sovereign ratings on foreign-currency-denominated debt are generally more significant for the G7 banks' lending to investment-grade borrowers whereas ratings on local-currency-denominated debt play a greater role in non-investmentgrade lending. However, in both cases, outlook revisions are less important than actual rating changes consistent with the full sample results discussed above. The sub-sample results for different investment grades is illuminating as it suggests that lenders from developed markets base their lending decisions on different types of ratings information depending on the investment grade of the country to which they are lending. In the investment-grade spectrum, lenders look to ratings on foreign currency debt as their primary concern is with the borrower's ability to repay and service their debt in hard currency whereas at the speculative end, the borrower's fundamental ability to fulfill their debt obligations is more of the concern for international bank lenders and so they instead focus on local currency debt ratings to monitor local economic and political developments that would impact on the credit risks. This substantiates the usefulness of the broad range of sovereign ratings information provided by credit rating agencies such as S\&P.

[INSERT TABLE 2] 
As with the full sample estimation results, in Table 2, we also find other significant determinants for international bank flows. However, what is striking is that there is consistent evidence on the differential importance of our prior set of determinants conditional on the creditworthiness of target countries.

Firstly, we reveal a greater importance of bilateral linkages for non-investment-grade lending as the coefficient on DIST is negative and significant for bank flows from Germany, Italy, Japan and UK. The cultural and legal origin linkages are also particularly important for speculative grade lending as the shared ENG and CMLW dummy variables are only significant and positive for Canada, UK and the US's non-investment-grade lending. EU members from emerging Europe are preferred by banks in developed European countries but this preference is strongest for their lending to non-investment-grade markets. We also find that UK banks actually have a strong preference for non-investment-grade emerging European markets but are less inclined to lend to the investment-grade ones. The importance of cultural linkages in international lending decisions corroborates with Giannetti and Yafeh's (2010) results suggesting that culturally distant borrowers receive smaller loans at higher interest rates in the syndicated loan market. A shared CIVLW legal origin continues to be preferred by historically bank-centric Japan and Germany. Hence, whilst legal origin is clearly important, we cannot say whether common law which is based on intricate precedents and judges' discretion is any more effective for international banking than civil law as bank orientated systems are traditionally rooted in civil legal origins (La Porta et al. 1997). Political ties represented by aid donations (DON) remain important for both investment grades. Taken together, our results suggest that geographical proximity and cultural and legal linkages are only important for ameliorating informational asymmetries for more risky lending decisions to borrowers from non-investment-grade countries. This suggests that familiarity (reduced informational asymmetries) are particularly pertinent in swaying bank flows from rich to the 
lesser developed (lower rated) nations. This is a crucial finding for the literature and validates the apparent insignificance of bilateral linkage variables in our full sample results.

For the remaining economic and financial control variables, there are also differential responses for investment- and non-investment-grade flows. In terms of financial and economic development, economic (LGDP) and equity market (SMCAP) size exerts the expected pulling power in non-investment-grade lending in contrast to our full sample results (highly significant and positive for Germany, Italy, Japan, France and UK bank flows). Stock market performance (RSINDEXCH) is positively associated with investment-grade lending as these markets are typically the destinations with more developed and thriving financial markets. Consistent with this, the crowding out effect of stock market capitalization (SMCAP) for the bank flows is concentrated in investment-grade countries (suggesting intuitively that the crowding out effect is strongest in the latter stages of financial market development), In all other cases, the effects of the variables hold across both investment grades. The distinction in the influence of financial openness on international bank flows based on investment grade is also illuminating. Greater FDI flows to non-investment-grade markets actually work to encourage international lending from CAN and the U.S. and the negative influence of the FDI flows is mainly concentrated in investment-grade countries and significant for the flows from Germany and Japan. This suggests that financial openness is particularly important for stimulating international bank flows to destinations that are perceived to be more risky. This is also consistent with Rajan and Zingales (2003) theory that financial openness works to promote financial development by reducing the influence of interest groups in developing economies. As emerging economies become more open and financially developed, they have greater demands for international bank financing. In investment-grade emerging markets, multinational firms are more confident in making long term foreign direct investments and this source of foreign funding takes over the reliance on bank financing. Corroborating with 
this view, direct investment barriers (DBARR) reduce Italian and US bank flows to only investment-grade markets. Except for Italy and Japan, the coefficient for FXREGM is negative (and significant for Canada, France, Germany and the U.K.) for the investment-grade countries and positive (and significant for France, the U.K. and the U.S.) for the noninvestment-grade countries. This clearly suggests that the G7 banks in general prefer exchange rate flexibility for the investment grade borrowers while they value the monetary policy discipline that is associated with exchange rate controls in non-investment grade countries. The Italian banks prefer exchange rate controls for both types of borrower countries whereas the Japanese banks prefer floating rate regimes for both.

Lastly, we also find markedly consistent evidence on the differential importance of governance quality conditional on the creditworthiness of target countries. In comparing the results in Tables 1 and 2, we note that the overall estimation results are determined primarily by the non-investment-grade sub-group despite a fairly even number of observations in both grades of emerging markets. In the breakdown by investment grade, we find that governance and institutional quality is in fact important for investment-grade lending (from France and UK) but not for speculative-grade. The estimated coefficients on GOV for non-investmentgrade estimations are all negative and significant (except for Germany).This suggests that improvements in the aggregate governance quality of a lower rated country enables them to become less reliant on international bank financing as alternative forms of international capital flows become more accessible when investor protection visibly improves. As loan conditions are typically poorer for speculative-grade borrowers, they are more inclined to access alternative forms of financing when they can. Our differential findings for cultural and legal linkages in addition to the importance of governance quality in non-investment-grade borrowers is consistent with Stulz and Williamson's (2003) revelation that cultural differences around the world reflect how well investor protection and creditor rights can be enforced. If 
there is little cultural similarity with a low grade country to begin with, then governance quality becomes a secondary concern. Moreover, given that Bae and Goyal (2009) find banks receive higher loan spreads in countries with lower legal rights and enforcement, it is plausible that more aggressive banks in some G7 countries may opt to reduce their lending to emerging markets with improving governance but lowering interest spreads.

\section{Regional Rating Spillover Effects on Emerging Market Bank Flows}

We next turn to a regional analysis on the effect of emerging market sovereign rating revisions and their inter-regional spillover effects. The results on foreign currency rating spillover effects are first presented in Table 3.

\section{[INSERT TABLE 3]}

For the foreign currency rating spillover estimations, the impacts of own country ratings and outlook changes are subsumed by spillover effects from all other regions' ratings changes (with the exception of Emerging Europe's rating spillovers). The comprehensive credit rating spillover variables are both statistically and economically more significant than own country rating and outlook revisions as a one notch improvement in other regions' average ratings can move banking flows by ten folds or more than own country rating effects (based on the size of estimated coefficients). The highly significant principal component variable indicates that other relevant determinants for international bank flows are adequately controlled for in our rating spillover estimations.

Closer examination of the spillover coefficients for the four emerging market regions reveals a number of interesting patterns. First, negative spillovers from other emerging regions are widespread throughout emerging markets. That is, bank flows to individual emerging markets contract in response to improvements in credit assessments of other emerging regions. This implies that emerging market sovereign ratings have competitive 
(“crowding out”) effects on international bank flows as G7 lenders are drawn by rating improvements first at the aggregate regional level then the country level. The competitive effects may be due to relatively fixed loan portfolio allocations that banks in developed markets set for emerging markets in aggregate. Hence, as economic and political improvements (as indicated by rating/outlook upgrades) occur in one region, loanable funds are shifted away from other emerging markets in pursuit of the best risk-adjusted returns for bank shareholders. Alternatively the negative spillovers might be due to a lack of investment opportunities in the affected regions. That is, ratings improvements in one region draws loanable funds from other regions with insufficient investment potential.

Rating spillovers from the AP are a standout as they are consistently positive for countries in other emerging regions. This suggests that fundamental credit condition improvements in AP countries have largely complementary spillover effects for all emerging markets' access to international bank financing. In addition, the AP is the most important emerging market region in terms of attracting the most international bank flows. The average net claim of the G7 banks against AP countries over the sample period is US\$55 trillion whereas the overall average for all four regions is US\$22 trillion. ${ }^{10}$ Therefore, it can be argued that when the G7 banks decide to increase their exposure to emerging markets, they explore the AP first and then the other regions which would explain the unambiguous positive ratings spillovers from the AP. However, once portfolio allocations to emerging markets are strategically increased, the G7 banks then selectively choose to focus on other regions with rating improvements at the expense of AP borrowers. For this reason, rating spillovers to AP from other regions are all negative.

\footnotetext{
${ }^{10}$ The overall average claims of G7 banks on the other three emerging market regions are US\$8.1 (LA), US\$15.1 (AME) and US\$14 trillion (EE) for the full sample from 1995-2008.
} 
Lastly, we note that the bank flows to LA and AME countries are mostly dependent on each other's regional rating events (not AP or EE). Credit improvements in these two regions are highly competitive for international bank flows.

Local currency rating spillover effects are shown in Table 4. The spillover effects are noticeably less pronounced compared to the foreign currency spillovers (especially those of EE) but the direction of regional rating spillovers remain largely the same. Whilst negative ratings spillover from LA and AME remains significant and negative in nearly all cases, the spillovers from EE exert next to no impact on bank flows to other emerging countries. The positive rating spillovers from AP also remain, corroborating the importance of Asian sovereign ratings in attracting international bank flows for all emerging markets over our sample period.

\section{[INSERT TABLE 4]}

To explore potential time variations in rating spillover effects on international bank flows, we report in Table 5 our sub-sample results. We break the sample at the end of 2003 as there is a significant and noticeable structural break in international bank flows to emerging markets in 2003. Bank inflows to the emerging market regions collapsed in the last quarter of 1997 (coinciding with the Asian Financial Crisis) and remained at low levels before picking up in 2003. This prolonged period of depressed bank flows is most likely due to the various emerging market crises that took place from 1997-98 (Asian and Russian crises) to the end of the Argentine crisis. Hence, the two sub-samples reveal marked changes in the patterns of rating spillovers. The spillover coefficients from AP and EE are positive in the first sample and negative or insignificant in the second in all cases whilst spillover from LA and AME remained negative throughout both sub-sample periods. ${ }^{11}$ Positive spillovers in the earlier sub-sample period that was dominated by various financial crises is largely consistent with

\footnotetext{
${ }^{11}$ This result is robust to an exclusion of the last quarter of 2008, after Lehman Brother's collapse.
} 
Van Rijckeghem and Weder’s (2003) finding that banks withdraw from even non-crisis hit countries when they suffer losses in some other markets during financial crises. This change in the direction of rating spillovers can be interpreted in two ways. First, it could be that rating events in AP and EE initially acted as a conduit for the G7 banks to increase their exposure to the emerging markets as a whole. Then, once the G7 lenders re-entered the emerging markets, the bank flows to each of the emerging market regions crowded each other out. ${ }^{12}$ Alternatively, rating declines for AP and EE countries during the Asian and Russian financial crises worked to decrease bank flows to all emerging markets, but subsequent improvements in credit conditions (in the second subsample) pulled bank flows back to AP countries at the expense of others.

\section{[INSERT TABLE 5]}

In sum, we document the important roles that sovereign ratings play in determining the G7's bank lending flows to emerging markets. International bank flows are influenced not only by the sovereign ratings and outlooks of the recipient countries but also by the average ratings of other emerging market regions. Whilst there is a strong positive relationship between own country ratings and outlooks with incoming bank flows, spillover influences of other emerging market regions’ foreign currency debt ratings are also strongly present.

\section{Conclusions}

We investigate the influence of different types of sovereign credit rating information on variations in international bank flows to emerging market economies. Specifically, we find G7 bank flows are influenced by various measures of credit quality for target destinations. Firstly, we find evidence indicating that sovereign credit rating and outlooks have strong positive effects on international bank flows from developed markets to emerging market

\footnotetext{
${ }^{12}$ The subsample analyses for local currency ratings spillovers show similar but weaker results. We do not report these results for brevity but they are available upon request.
} 
borrowers even after controlling for a host of bilateral linkages and other determinants. Secondly, our sub-sample evidence suggests that foreign currency ratings information are more influential for bank lending to investment-grade borrowers, whilst lending decisions to non-investment-grade countries are swayed more by local currency rating assessments. Thirdly, we find that informational asymmetries are only of concern in international bank lending to more risky non-investment-grade destinations as international lenders have a clear preference for choosing more familiar emerging market targets that share their own cultural and legal backgrounds. However, they also show higher risk appetite for taking credit positions against non-investment-grade countries with lower governance quality and tighter foreign exchange controls.

Finally, we report significant rating spillover effects. For the full sample, we find generally negative spillover effects where ratings improvements in one region pulls the bank flows away from the others. Yet, we find a complementary influence of Asian rating events on the bank flows to all emerging market bank flows. In sub-sample analyses, we find that the positive spillover effects are concentrated in the earlier sub-sample pre-2003. In contrast, since 2003 ratings improvements in the Asian and European regions have effectively reduced the bank flows heading to the other regions. Taken together, sovereign credit ratings have unequivocal informational value for international bank lending decisions.

From a policy perspective, these findings imply that emerging market governments can play a vital role for banking liquidity and economic development and should cooperate with rating agencies in the consistent provision of relevant and timely information for the ongoing country rating process. The independence of rating agencies is critical for international banking regulatory guidelines to remain effective as credit rating agencies do appear to play a role in ameliorating the monitoring costs in international bank lending activities. 
Our study is not without its limitations. As we do not capture off-balance sheet positions of the G7 banks in emerging markets, it is likely that our results understate the importance of sovereign ratings on international banking activities. Yet our consistently robust results in this study suggest that a significant influence of ratings information on international bank flows cannot be denied. Moreover, although we have only explored the influence of agency credit ratings in the context of "pull” factors in emerging markets, we are aware that push factors in G7 economies themselves may well have also affected international bank flows. However, for most of the sample period, growth in the developed world has been strong and international bank flows have been largely pro-cyclical. Thus, we leave the analyses of push factors to future research. 
Appendix A

TABLE A1. List of Emerging Market Countries Studied

\begin{tabular}{|c|c|c|c|}
\hline Asia & $\begin{array}{l}\text { Africa/Middle } \\
\text { East }\end{array}$ & $\begin{array}{c}\text { Emerging } \\
\text { Europe }\end{array}$ & Latin America \\
\hline (10) & (9) & (17) & (19) \\
\hline China & Egypt & Bulgaria & Argentina \\
\hline Hong Kong & Israel & Croatia & Barbados \\
\hline India & Jordan & Cyprus & Bolivia \\
\hline Indonesia & Lebanon & $\begin{array}{c}\text { Czech } \\
\text { Republic }\end{array}$ & Brazil \\
\hline Kazahkstan & Morroco & Estonia & Chile \\
\hline Korea & Oman & Hungary & Colombia \\
\hline Malaysia & Qatar & Iceland & Costa Rica \\
\hline Pakistan & South Africa & Latvia & $\begin{array}{l}\text { Dominican } \\
\text { Republic }\end{array}$ \\
\hline Philippines & Tunisia & Lithuania & Ecuador \\
\hline \multirow[t]{9}{*}{ Thailand } & & Malta & El Salvador \\
\hline & & Poland & Guatemala \\
\hline & & Romania & Jamaica \\
\hline & & Russia & Mexico \\
\hline & & $\begin{array}{c}\text { Slovak } \\
\text { Republic }\end{array}$ & Panama \\
\hline & & Slovenia & Paraguay \\
\hline & & Turkey & Peru \\
\hline & & Ukraine & Uruguay \\
\hline & & & Venezuela \\
\hline
\end{tabular}




\section{Appendix B}

\section{TABLE B1. Variable Definitions and Data Sources}

\begin{tabular}{|c|c|c|}
\hline Variables & Descriptions & Data Sources \\
\hline G-7 BankFlows & $\begin{array}{l}\text { Quarterly change in G-7 banks' end-year foreign claims against each of the } 55 \\
\text { emerging market countries, in US\$ billions. }\end{array}$ & $\begin{array}{l}\text { BIS's consolidated banking statistics, } \\
\text { Table 9B: Consolidated foreign claims of reporting banks - immediate } \\
\text { borrower basis (http://www.bis.org/statistics/consstats.htm) }\end{array}$ \\
\hline Sovereign credit ratings & & Standard \& Poor's \\
\hline Credit Rating_FCurrency & Foreign currency sovereign long-term credit rating & \\
\hline Outlook_FCurrency & Foreign currency outlook of long-term sovereign rating & \\
\hline Credit Rating_LCurrency & Local currency sovereign long-term credit rating & \\
\hline Outlook_LCurrency & Local currency outlook of long-term sovereign rating & \\
\hline \multicolumn{3}{|l|}{ Bilateral Linkage } \\
\hline Distance (DIST) & $\begin{array}{l}\text { Natural log of distance between capital cities of the target and donor country pairs } \\
\text { in kilometers }\end{array}$ & $\begin{array}{l}\text { Calculated from coordinates of capital cities obtained from CIA's world } \\
\text { factbook: } \\
\text { https://www.cia.gov/library/publications/the-world-factbook/ }\end{array}$ \\
\hline Total Trade (TOTTRADE) & $\begin{array}{l}\text { Sum of export and import between the target and donor country pairs in natural } \\
\text { logs, US\$ }\end{array}$ & $\begin{array}{l}\text { IMF's direction of trade statistics: } \\
\text { http://fisher.lib.virginia.edu/collections/stats/dot/ }\end{array}$ \\
\hline Donation Flows (DON) & Official aid flows from each G7 to emerging country, in US\$ millions, natural logs & World Bank development indicators CD-ROM, 2009 \\
\hline English Language link (ENG) & Dummy variable $=1$ if donor/target country pair shares English as an official or & CIA's world factbook \\
\hline European Union (EU) & Dummy variable $=1$ if donor/target country pair shares European Union & http://europa.eu/abc/european_countries/index_en.htm \\
\hline Common Law (CMLW) & Dummy variable $=1$ if donor/target country pair shares a commonlaw legal origin, & La Porta et al. (1997) \\
\hline Civil Law (CIVLW) & Dummy variable $=1$ if donor/target country pair shares a civil law legal origin, $=0$ & La Porta et al. (1997) \\
\hline Economic and Financial Development & & World Bank development indicators CD-ROM, 2009 \\
\hline GDP (LGDP) & GDP in natural logs, US\$ & \\
\hline Stock Market Capitalization (SMCAP) & Market capitalization of listed companies at the end of year in natural logs, US\$ & \\
\hline Banks Credit Extended (BANKCRED) & Domestic credit provided by banking sector in natural logs, US\$ & \\
\hline Interest Rate Spread (INTSPREAD) & Difference between lending and deposit rates in percentage points & \\
\hline $\begin{array}{l}\text { Bank Liquid Reserves to Asset Ratio } \\
\text { (LIQTOASSET) }\end{array}$ & Ratio of liquid assets to total assets & \\
\hline \multicolumn{3}{|l|}{ Financial Openness } \\
\hline FDI on BOP basis (FDI) & FDI inflows in natural logs, US\$ & World Bank development indicators CD-ROM, 2009 \\
\hline Total Portfolio inflow (PORTFOLIO) & Sum of bond and equity portfolio investment inflows in natural logs, US\$ & \\
\hline Domestic Barriers to Investments (DBARR) & Investment restrictions on direct investment & IMF's annual reports on exchange arrangements and restrictions 1995-2007 \\
\hline Foreign Barriers to Investments (FBARR) & Investment restrictions on financial credit & IMF's annual reports on exchange arrangements and restrictions 1995-2007 \\
\hline Foreign Exchange Regime (FXREGM) & $\begin{array}{l}4=\text { Dollarization, } 3 \text { = Curreny board, } 2 \text { = Currency pegs, } 1 \text { = Crawling pegs, } \\
0=\text { Floating }\end{array}$ & $\begin{array}{l}\text { IMF's Classification of Exchange Rate Arrangements and Monetary } \\
\text { Frameworks, http://www.imf.org/external/np/mfd/er/index.asp } \\
\text { IMF's Annual Report on Exchange Arrangements and Exchange Restrictions, } \\
\text { Various issues. }\end{array}$ \\
\hline \multicolumn{3}{|l|}{ Governance and Institutional Quality } \\
\hline $\begin{array}{l}\text { World Bank Governance indicators } \\
\text { - Composite measure (Gov) }\end{array}$ & $\begin{array}{l}\text { Aggregate of individual governance measure - Accountability, Political stability, } \\
\text { Governance effectiveness, Regulation quality, Rule of Law and Corruption - each } \\
\text { ranges from }-2.5 \text { to } 2.5\end{array}$ & Kauffman, Kraay, and Mastruzzi (2009) \\
\hline
\end{tabular}




\section{References}

Bae, K-H., and V. Goyal, 2009, Creditor rights, enforcements, and bank loans, Journal of Finance 64, 823-860.

Bekaert, G., and X. Wang, 2009, Globalization and asset prices, Working paper, Columbia University.

Boot, A.W., T.T. Milbourne, and A. Schmeits, 2005, Credit ratings as coordination mechanisms, Review of Financial Studies 19, 81-118.

Brooks, R., R. Faff, D. Hillier, and J. Hillier, 2004, The national market impact of sovereign rating changes, Journal of Banking and Finance 28, 233-250.

Buch, C., 2000, Why do banks go abroad? Evidence from German data, Financial Markets, Institutions and Instruments 9, 24-67.

Buch, C., 2003, Information or regulation: What drives the international activities of commercial banks? Journal of Money, Credit and Banking 35, 851-869.

Buch, C., 2005, Distance and International Banking, Review of International Economics 13, 787-804.

Butler, A., and L. Fauver, 2006, Institutional Environment and Sovereign Credit Ratings, Financial Management Autumn, 53-79.

Cantor, R., and F. Packer, 1996, Determinants and impact of sovereign credit ratings, Federal Reserve Bank of New York Economic Policy Review 2, 37-53.

Chiang, T.C., Jeon B.N., and H., Li, 2007, Dynamic correlation analysis of financial contagion: Evidence from Asian markets, Journal of International Money and Finance 26, 1206-1228.

Claessens, S., and L. Laeven, 2004, What Drives Bank Competition? Some International Evidence, Journal of Money, Credit, and Banking 36, 563-583.

Coval, J. D., and T. J. Moskowitz, 1999, Home Bias at Home: Local Equity Preference in 
Domestic Portfolios, Journal of Finance 54, 2045-2073.

Dahl, D., and R.E. Shrieves, 1999, The extensions of international credit by US banks: A disaggregated analysis 1988-1994, Journal of International Money and Finance 18, 153-167.

Durbin, E., and D. Ng, 2005. The sovereign ceiling and emerging market corporate bond spreads, Journal of International Money and Finance 24, 631-649.

Diamond, D.W., 1984, Financial intermediation and delegated monitoring, Review of Economic Studies 51, 393-414.

Faccio, M., R.W. Masulis, and J.J. McConnell, 2006, Political connections and corporate bailouts, Journal of Finance 61, 2597-2635.

Ferreira, M.A., and P.M., Gama, 2007, Does sovereign debt ratings news spill over to international stock markets? Journal of Banking and Finance 31, 3162-3182.

Gande, A., and D.C. Parsley, 2005, News spillovers in the sovereign debt market, Journal of Financial Economics 75, 691-734.

Giannetti, M., and Y. Yafeh, 2010, Do cultural differences between contracting parties matter? Evidence from syndicated bank loans, Working paper, Stockholm School of Economics.

Guiso, L., P. Sapienza, and L. Zingales, 2006, Does culture affect economic outcomes? Journal of Economic Perspectives 20, 23-48.

Herrero, A. G., and M.S. Martinez-Peria, 2007, The mix of international banks' foreign claims: Determinants and implications, Journal of Banking and Finance 31, 16131631.

Kaminsky G., and S.L. Schmukler, 1999, What triggers market jitters? A chronicle of the Asian crisis, Journal of International Money and Finance 18, 537-560.

Kaminsky, G., and S.L. Schmukler, 2002, Emerging markets instability: do sovereign ratings 
affect country risk and stock returns? World Bank Economic Review 16, 171-195.

Kaufmann, D., A. Kraay, and M. Mastruzzi, 2009, Governance Matters VII: Governance Indicators for 1996-2008, World Bank Policy Research Working Paper 4978, Washington, D.C.

Kim, S-J., and E. Wu, 2008, Sovereign credit ratings, capital flows and financial sector development in emerging markets, Emerging Markets Review 9, 17-39.

La Porta, R., F. Lopez-De-Silanes, A. Shleifer, and R. Vishny, 1997, Legal determinants of external finance, Journal of Finance 52, 1131-1150.

Levine, R., and S. Zervos, 1998, Stock markets, banks and economic growth, American Economic Review 88, 537-558.

Merrill Lynch, 1999. Why Do Bond Rating Agencies Exist? Extra Credit, November, New York.

Papaioannou, E., 2009, What drives international bank flows? Politics, Institutions and other determinants, Journal of Development Economics 88, 269-281

Portes, R., and H. Rey, 2005, The determinants of cross-border equity flows, Journal of International Economics 65, 269-296.

Rajan, R., and L. Zingales, 2003, The great reversals: the politics of financial development in the twentieth century, Journal of Financial Economics 69, 5-50.

Stulz, R., and R. Williamson, 2003, Culture, openness and finance, Journal of Financial Economics, 70, 313-349.

Van Rijckeghem, C., and B. Weder, 2003, Spillovers through banking centers: a panel data analysis of bank flows, Journal of International Money and Finance 22, 483-509.

Yi, H-C., and D.J. Mullineaux, 2006,. The informational role of bank loan ratings, Journal of Financial Research 29, 481-501. 
TABLE 1. Overall Foreign and Local Currency Rating Estimations: 1995-2008.

\begin{tabular}{|c|c|c|c|c|c|c|c|}
\hline & Canada & France & Germany & Italy & Japan & UK & US \\
\hline \multicolumn{8}{|c|}{ Panel A. Foreign Currency Ratings and Outlooks } \\
\hline \multirow[t]{2}{*}{$\Delta \mathrm{CR}$} & 0.0343 & $0.4703 * * *$ & $0.72 * * *$ & $0.1836^{*}$ & $0.8118^{* *}$ & -0.2905 & $0.9009 * * *$ \\
\hline & $\{.4596\}$ & $\{.0000\}$ & $\{.0000\}$ & $\{.0859\}$ & $\{.0305\}$ & $\{.4138\}$ & $\{.0039\}$ \\
\hline \multirow[t]{2}{*}{$\Delta$ Outlook } & 0.3156 & 1.0646 & $2.6303 * *$ & -0.2353 & 1.7332 & 2.18 & $3.5394^{*}$ \\
\hline & $\{.2680\}$ & $\{.1162\}$ & $\{.0152\}$ & $\{.7246\}$ & $\{.4581\}$ & $\{.2971\}$ & $\{.0753\}$ \\
\hline \multicolumn{8}{|c|}{ Panel B. Local Currency Ratings and Outlooks } \\
\hline \multirow[t]{2}{*}{$\Delta \mathrm{CR}$} & 0.0034 & $0.3071^{* * *}$ & $0.3086 *$ & 0.1652 & $0.8234^{* *}$ & -0.4917 & $0.5675 *$ \\
\hline & $\{.9426\}$ & $\{.0071\}$ & $\{.0842\}$ & $\{.1717\}$ & $\{.0324\}$ & $\{.2088\}$ & $\{.0845\}$ \\
\hline \multirow[t]{2}{*}{$\Delta$ Outlook } & 0.2919 & 0.8832 & $2.2439 * *$ & -0.2452 & 1.5541 & 2.1552 & $3.3828 *$ \\
\hline & $\{.3039\}$ & $\{.1922\}$ & $\{.0381\}$ & $\{.7149\}$ & $\{.5047\}$ & $\{.3013\}$ & $\{.0908\}$ \\
\hline \multicolumn{8}{|c|}{ Panel C. Bilateral Linkage } \\
\hline \multirow[t]{2}{*}{ DIST } & $0.4108 * * *$ & $0.3987 * * *$ & $-0.4527 * *$ & 0.1298 & $4.46 * * *$ & -0.0141 & $6.9691 * * *$ \\
\hline & $\{.0000\}$ & $\{.0009\}$ & $\{.0180\}$ & $\{.2642\}$ & $\{.0000\}$ & $\{.9708\}$ & $\{.0000\}$ \\
\hline \multirow[t]{2}{*}{ TOTTRADE } & $-0.1163 * * *$ & $-1.3693 * * *$ & $-2.685 * * *$ & $-0.4861 * * *$ & $-0.7685 * * *$ & $-2.1111^{* * *}$ & $-1.4711 * * *$ \\
\hline & $\{.0000\}$ & $\{.0000\}$ & $\{.0000\}$ & $\{.0000\}$ & $\{.0000\}$ & $\{.0000\}$ & $\{.0000\}$ \\
\hline \multirow[t]{2}{*}{$\mathrm{DON}$} & $0.1009 * * *$ & $0.3107 * * *$ & $0.529 * * *$ & $-0.0584^{* *}$ & $-0.2723 * * *$ & $0.4123 * * *$ & $1.0634^{* * *}$ \\
\hline & $\{.0000\}$ & $\{.0000\}$ & $\{.0000\}$ & $\{.0162\}$ & $\{.0061\}$ & $\{.0000\}$ & $\{.0000\}$ \\
\hline \multirow[t]{2}{*}{ ENG } & $-0.2866 * * *$ & & & & & $-5.4493 * * *$ & 0.6139 \\
\hline & $\{.0008\}$ & & & & & $\{.0000\}$ & $\{.2563\}$ \\
\hline \multirow[t]{2}{*}{ EU } & & $1.9999 * * *$ & $3.0713 * * *$ & $0.8796 * * *$ & & $-1.3077^{* *}$ & \\
\hline & & $\{.0000\}$ & $\{.0000\}$ & $\{.0000\}$ & & $\{.0417\}$ & \\
\hline \multirow[t]{2}{*}{ CMLW } & $0.5034 * * *$ & & & & & $-4.9609 * * *$ & $4.3628 * * *$ \\
\hline & $\{.0000\}$ & & & & & $\{.0000\}$ & $\{.0000\}$ \\
\hline \multirow[t]{2}{*}{ CIVLW } & & -0.0655 & $1.662 * * *$ & $-0.2729 * *$ & $1.6941^{* * *}$ & & \\
\hline & & $\{.5945\}$ & $\{.0000\}$ & $\{.0255\}$ & $\{.0001\}$ & & \\
\hline
\end{tabular}


Note: This table presents the overall results for the panel data specifications shown below:

G7BanFl ows $s_{i, t}^{j}=$

$\alpha+\beta_{1} \cdot \Delta C R_{i, t-1}+\beta_{2} \cdot \Delta$ Outlook $_{i, t-1}+\sum_{k=3}^{p} \beta_{k} \cdot$ Bilateral_links $s_{i, t}^{k}+\sum_{k=10}^{q} \beta_{k} \cdot$ Fin_devmt $_{i, t}^{k}+\sum_{k=16}^{r} \beta_{k} \cdot$ Fin_open $_{i, t}^{k}+\beta_{20} \cdot$ Gov $_{i, t}$ (1)

Where G7BankFlows are the quarterly changes in foreign claims of G7 countries' banks against 55 emerging market countries. CR and Outlook are sovereign credit ratings and outlooks of the emerging market countries for foreign- and local-currency-denominated debt. The control variables incorporate country-specific variables. Numbers in braces are $p$-values.

$* * *$ Significant at the $1 \%$ level.

**Significant at the $5 \%$ level.

*Significant at the $10 \%$ level. 
TABLE 1. - Continued

\begin{tabular}{|c|c|c|c|c|c|c|c|}
\hline & Canada & France & Germany & Italy & Japan & UK & US \\
\hline \multicolumn{8}{|c|}{ Panel D. Economic and Financial Development } \\
\hline \multirow[t]{2}{*}{ LGDP } & $-0.1963 * * *$ & $-0.1208 * *$ & $0.2315^{* *}$ & 0.0247 & $-1.5059 * * *$ & 0.2195 & $-3.0994 * * *$ \\
\hline & $\{.0000\}$ & $\{.0420\}$ & $\{.0204\}$ & $\{.6869\}$ & $\{.0000\}$ & $\{.2125\}$ & $\{.0000\}$ \\
\hline \multirow[t]{2}{*}{ SMCAP } & $-0.0032 * * *$ & $-0.0149 * * *$ & $-0.0102 * * *$ & $0.0069 * * *$ & $-0.0405 * * *$ & $-0.0655 * * *$ & $-0.014 * * *$ \\
\hline & $\{.0000\}$ & $\{.0000\}$ & $\{.0000\}$ & $\{.0000\}$ & $\{.0000\}$ & $\{.0000\}$ & $\{.0002\}$ \\
\hline \multirow[t]{2}{*}{ BANKCRED } & 0.0001 & -0.0021 & $0.008 * * *$ & $0.0033^{* *}$ & $-0.0131 * * *$ & $-0.0195 * * *$ & -0.0063 \\
\hline & $\{.8799\}$ & $\{.1467\}$ & $\{.0005\}$ & $\{.0133\}$ & $\{.0062\}$ & $\{.0000\}$ & $\{.1786\}$ \\
\hline \multirow[t]{2}{*}{ INTSPREAD } & -0.0023 & $-0.0111 * * *$ & $-0.0475 * * *$ & $-0.0239 * * *$ & 0.0061 & $-0.0337 * * *$ & $-0.035 * * *$ \\
\hline & $\{.1714\}$ & $\{.0003\}$ & $\{.0000\}$ & $\{.0000\}$ & $\{.5654\}$ & $\{.0003\}$ & $\{.0029\}$ \\
\hline \multirow[t]{2}{*}{ LIQTOASSET } & $0.0065 * * *$ & $0.013 * *$ & $0.0496 * * *$ & $0.0216 * * *$ & $0.0481 * *$ & $0.0366 * *$ & $0.127 * * *$ \\
\hline & $\{.0088\}$ & $\{.0208\}$ & $\{.0000\}$ & $\{.0002\}$ & $\{.0277\}$ & $\{.0410\}$ & $\{.0000\}$ \\
\hline \multirow[t]{2}{*}{ RSINDEXCH } & $0.4324 * *$ & $1.0527 * * *$ & 1.043 & 0.23 & 2.6733 & $4.0397 * * *$ & $1.1499 *$ \\
\hline & $\{.0399\}$ & $\{.0032\}$ & $\{.2147\}$ & $\{.5880\}$ & $\{.1241\}$ & $\{.0030\}$ & $\{.0523\}$ \\
\hline \multicolumn{8}{|c|}{ Panel E. Financial Openness } \\
\hline \multirow[t]{2}{*}{ FDI } & 0.0055 & $-0.0369 * * *$ & -0.0415 & $-0.042 * * *$ & $-0.3129 * * *$ & 0.0528 & 0.0063 \\
\hline & $\{.4057\}$ & $\{.0089\}$ & $\{.1087\}$ & $\{.0076\}$ & $\{.0000\}$ & $\{.2837\}$ & $\{.8902\}$ \\
\hline \multirow[t]{2}{*}{ PORTFOLIO } & $-0.0001 * * *$ & $-0.0003^{* * *}$ & $-0.0006 * * *$ & $-0.0002 * * *$ & $-0.0009 * * *$ & $-0.0017 * * *$ & $-0.0011 * * *$ \\
\hline & $\{.0000\}$ & $\{.0000\}$ & $\{.0000\}$ & $\{.0000\}$ & $\{.0000\}$ & $\{.0000\}$ & $\{.0000\}$ \\
\hline \multirow[t]{2}{*}{ DBARR } & $-0.1161 * *$ & 0.0704 & $0.8835 * * *$ & $0.3255^{* * *}$ & $2.448 * * *$ & 0.5796 & $-0.8373 * *$ \\
\hline & $\{.0213\}$ & $\{.5454\}$ & $\{.0000\}$ & $\{.0073\}$ & $\{.0000\}$ & $\{.1268\}$ & $\{.0216\}$ \\
\hline \multirow[t]{2}{*}{ FBARR } & $0.1347 * *$ & $0.8577 * * *$ & $1.4332 * * *$ & $0.3425 * *$ & $5.2911 * * *$ & $2.6839 * * *$ & $1.005^{* *}$ \\
\hline & $\{.0130\}$ & $\{.0000\}$ & $\{.0000\}$ & $\{.0110\}$ & $\{.0000\}$ & $\{.0000\}$ & $\{.0104\}$ \\
\hline \multirow[t]{2}{*}{ FXREGM } & -0.0189 & $-0.1884 * * *$ & -0.016 & $0.1597 * * *$ & $-1.2969 * * *$ & $-0.6565 * * *$ & $0.3179 * *$ \\
\hline & $\{.2995\}$ & $\{.0000\}$ & $\{.8190\}$ & $\{.0003\}$ & $\{.0000\}$ & $\{.0000\}$ & $\{.0183\}$ \\
\hline \multicolumn{8}{|c|}{ Panel F. Governance and Institutional Quality } \\
\hline \multirow[t]{2}{*}{ Gov } & -0.0126 & $0.0809 * * *$ & 0.0155 & $-0.0998 * * *$ & -0.0771 & $0.4313 * * *$ & -0.0326 \\
\hline & $\{.1253\}$ & $\{.0000\}$ & $\{.6712\}$ & $\{.0000\}$ & $\{.2329\}$ & $\{.0000\}$ & $\{.5797\}$ \\
\hline Likelihood & -3134 & -4871 & -5790 & -3034 & -7102 & -6444 & -7552 \\
\hline Nobs & 2230 & 2158 & 2106 & 1496 & 2060 & 1926 & 2230 \\
\hline
\end{tabular}




\section{TABLE 2. Investment- and Non-investment-grade Estimations}

\begin{tabular}{|c|c|c|c|c|c|c|c|c|c|c|c|c|c|c|}
\hline & Canada & & France & & Germany & & Italy & & Japan & & UK & & US & \\
\hline & INV & Non_INV & INV & Non_INV & INV & Non_INV & INV & Non_INV & INV & Non_INV & INV & Non_INV & INV & Non_INV \\
\hline Panel A. For & urrency Rating & s and Outlooks & & & & & & & & & & & & \\
\hline$\Delta \mathrm{CR}$ & 0.1404 & -0.0053 & $0.8544 * * *$ & $0.3411 * * *$ & $1.1554^{* * *}$ & $0.4497 * * *$ & 0.3476 & 0.1386 & 1.3204 & $0.5368 * * *$ & $-2.5102 * * *$ & 0.0151 & 1.1763 & $0.3937 * *$ \\
\hline & $\{.2729\}$ & $\{.7966\}$ & $\{.0014\}$ & $\{.0000\}$ & $\{.0010\}$ & $\{.0073\}$ & $\{.1503\}$ & $\{.1387\}$ & $\{.2540\}$ & $\{.0000\}$ & $\{.0081\}$ & $\{.9101\}$ & $\{.1277\}$ & $\{.0491\}$ \\
\hline$\Delta$ Outlook & 0.9763 & 0.0298 & $2.4583^{*}$ & 0.0791 & $5.3104 * * *$ & 0.7072 & -1.0947 & 0.4048 & 3.6798 & 0.9161 & 0.0456 & 0.4184 & 4.2787 & 1.2818 \\
\hline & $\{.1041\}$ & $\{.8324\}$ & $\{.0561\}$ & $\{.8801\}$ & $\{.0014\}$ & $\{.5440\}$ & $\{.3882\}$ & $\{.5215\}$ & $\{.4177\}$ & $\{.3113\}$ & $\{.9904\}$ & $\{.6457\}$ & $\{.2519\}$ & $\{.3546\}$ \\
\hline Panel B. Loc & reny Ratings a & d Outlooks & & & & & & & & & & & & \\
\hline$\Delta \mathrm{CR}$ & 0.0008 & 0.0021 & 0.4216 & $0.2545^{* * *}$ & $0.9157 * *$ & -0.0159 & 0.3955 & 0.0512 & -0.1439 & $0.6788^{* * *}$ & $-3.9232 * * *$ & 0.0395 & -0.1333 & $0.5^{* *}$ \\
\hline & $\{.9953\}$ & $\{.9205\}$ & $\{.1539\}$ & $\{.0011\}$ & $\{.0197\}$ & $\{.9232\}$ & $\{.1388\}$ & $\{.6327\}$ & $\{.9052\}$ & $\{.0000\}$ & $\{.0001\}$ & $\{.7910\}$ & $\{.8750\}$ & $\{.0136\}$ \\
\hline$\Delta$ Outlook & 0.7659 & 0.0321 & 1.4114 & 0.1187 & $4.2054 * * *$ & 0.5714 & -1.3301 & 0.3852 & 2.0383 & 1.0135 & 1.7491 & 0.4331 & 2.5267 & 1.3866 \\
\hline & $\{.1837\}$ & $\{.8200\}$ & $\{.2541\}$ & $\{.8218\}$ & $\{.0088\}$ & $\{.6252\}$ & $\{.2778\}$ & $\{.5468\}$ & $\{.6401\}$ & $\{.2614\}$ & $\{.6281\}$ & $\{.6349\}$ & $\{.4839\}$ & $\{.3170\}$ \\
\hline Panel C. Bila & Ginkage & & & & & & & & & & & & & \\
\hline DIST & $1.0102^{* * *}$ & 0.0503 & $1.2059 * * *$ & 0.1709 & $1.561^{* * *}$ & $-4.3309 * * *$ & $0.6942 * * *$ & $-0.3928 * *$ & $7.9547 * * *$ & $-1.5583 * * *$ & $2.7011^{* * *}$ & $-1.3173 * * *$ & $11.0709 * * *$ & $3.7344 * * *$ \\
\hline & $\{.0000\}$ & $\{.3043\}$ & $\{.0000\}$ & $\{.2758\}$ & $\{.0000\}$ & $\{.0000\}$ & $\{.0001\}$ & $\{.0169\}$ & $\{.0000\}$ & $\{.0000\}$ & $\{.0000\}$ & $\{.0000\}$ & $\{.0000\}$ & $\{.0000\}$ \\
\hline TOTTRADE & -0.0649 & $-0.1173 * * *$ & $-1.5637 * * *$ & $-1.1136 * * *$ & $-1.6401 * * *$ & $-4.8685 * * *$ & -0.0738 & $-0.8369 * * *$ & 0.1865 & $-2.3939 * * *$ & $-2.333 * * *$ & $-1.5474 * * *$ & $-1.6097 * * *$ & $-0.9579 * * *$ \\
\hline & $\{.1425\}$ & $\{.0000\}$ & $\{.0000\}$ & $\{.0000\}$ & $\{.0000\}$ & $\{.0000\}$ & $\{.5791\}$ & $\{.0000\}$ & $\{.4504\}$ & $\{.0000\}$ & $\{.0000\}$ & $\{.0000\}$ & $\{.0000\}$ & $\{.0000\}$ \\
\hline DON & $0.1272^{* * *}$ & $0.0834 * * *$ & $0.5285^{* * *}$ & $0.4096 * * *$ & $0.5916^{* * *}$ & -0.1583 & 0.0106 & -0.0429 & -0.1661 & -0.0781 & $0.6307 * * *$ & $0.195^{* * *}$ & $1.3145^{* * *}$ & $1.4211^{* * *}$ \\
\hline & $\{.0000\}$ & $\{.0000\}$ & $\{.0000\}$ & $\{.0000\}$ & $\{.0000\}$ & $\{.1045\}$ & $\{.7723\}$ & $\{.2063\}$ & $\{.3302\}$ & $\{.1001\}$ & $\{.0000\}$ & $\{.0000\}$ & $\{.0000\}$ & $\{.0000\}$ \\
\hline ENG & $-0.8805^{* * *}$ & $0.3027 * * *$ & & & & & & & & & $-11.3948 * * *$ & $2.9823^{* * *}$ & $-2.9694 * * *$ & $3.0011^{* * *}$ \\
\hline & $\{.0000\}$ & $\{.0000\}$ & & & & & & & & & $\{.0000\}$ & $\{.0000\}$ & $\{.0012\}$ & $\{.0000\}$ \\
\hline $\mathrm{EU}$ & & & $1.8781^{* * *}$ & $1.5122^{* * *}$ & $3.2507 * * *$ & $4.0525^{* * *}$ & 0.3804 & $1.9485^{* * *}$ & & & -1.086 & $1.2777 * * *$ & & \\
\hline & & & $\{.0000\}$ & $\{.0000\}$ & $\{.0000\}$ & $\{.0000\}$ & $\{.1661\}$ & $\{.0000\}$ & & & $\{.2811\}$ & $\{.0009\}$ & & \\
\hline CMLW & $0.5794 * * *$ & $0.6272 * * *$ & & & & & & & & & -0.1264 & 0.7041 & $3.7351 * * *$ & 0.1095 \\
\hline & $\{.0002\}$ & $\{.0000\}$ & & & & & & & & & $\{.8984\}$ & $\{.2582\}$ & $\{.0002\}$ & $\{.8474\}$ \\
\hline CIVLW & & & $-1.474 * * *$ & -0.1638 & -0.0554 & $2.6155^{* * *}$ & 0.3481 & $-0.7291 * * *$ & -0.0564 & $1.2222 * * *$ & & & & \\
\hline & & & $\{.0000\}$ & $\{.1303\}$ & $\{.8600\}$ & $\{.0000\}$ & $\{.1385\}$ & $\{.0000\}$ & $\{.9444\}$ & $\{.0000\}$ & & & & \\
\hline
\end{tabular}


Note: This table presents the separate panel estimation results of Eq (1) for two sub-groups of emerging markets - those with investment grade ratings (BBB- and above) and those with non-investment ratings ( $\mathrm{BB}+$ and below).

G7BankFlows $_{i, t}^{j}=\alpha+\beta_{1} \cdot \Delta C R_{i, t-1}+\beta_{2} \cdot \Delta$ Outlook $_{i, t-1}+\sum_{k=3}^{p} \beta_{k} \cdot$ Bilateral_links $_{i, t}^{k}+\sum_{k=10}^{q} \beta_{k} \cdot$ Fin_devmt $_{i, t}^{k}+\sum_{k=16}^{r} \beta_{k} \cdot$ Fin_open $_{i, t}^{k}+\beta_{20} \cdot$ Gov $_{i, t}$

Where G7BankFlows are the quarterly changes in foreign claims of G7 countries' banks against the two groups of emerging market borrowers. CR and Outlook are sovereign credit ratings and outlooks of the emerging market countries for foreign and local currency debt. The control variables incorporate country-specific variables. Numbers in braces are $p$-values.

$* * *$ Significant at the $1 \%$ level.

$* *$ Significant at the $5 \%$ level.

* Significant at the $10 \%$ level. 
TABLE 2. - Continued

\begin{tabular}{|c|c|c|c|c|c|c|c|c|c|c|c|c|c|c|}
\hline & \multicolumn{2}{|l|}{ Canada } & \multicolumn{2}{|l|}{ France } & \multicolumn{2}{|l|}{ Germany } & \multicolumn{2}{|l|}{ Italy } & \multicolumn{2}{|l|}{ Japan } & \multicolumn{2}{|l|}{ UK } & \multicolumn{2}{|l|}{ US } \\
\hline & INV & Non_INV & INV & Non_INV & INV & Non_INV & INV & Non_INV & INV & Non_INV & INV & Non_INV & INV & Non_INV \\
\hline \multicolumn{15}{|c|}{ Panel D. Economic and Financial Development } \\
\hline \multirow[t]{2}{*}{ LGDP } & $-0.4157^{* * *}$ & $-0.0623^{* * *}$ & $-0.4171^{* * *}$ & $-0.1493 *$ & $-0.7466 * * *$ & $2.5996 * * *$ & $-0.3017 * * *$ & $0.2701^{* * *}$ & $-2.968^{* * *}$ & $1.0668^{* * *}$ & $-0.4697 *$ & $0.5514 * * *$ & $-4.6681 * * *$ & $-2.2307^{* * *}$ \\
\hline & $\{.0000\}$ & $\{.0032\}$ & $\{.0000\}$ & $\{.0566\}$ & $\{.0000\}$ & $\{.0000\}$ & $\{.0009\}$ & $\{.0012\}$ & $\{.0000\}$ & $\{.0000\}$ & $\{.0757\}$ & $\{.0000\}$ & $\{.0000\}$ & $\{.0000\}$ \\
\hline \multirow[t]{2}{*}{ SMCAP } & $-0.0067 * * *$ & 0.0005 & $-0.0229 * * *$ & $0.0056^{* * *}$ & $-0.0133^{* * *}$ & $0.0074 * *$ & -0.0004 & $0.0121^{* * *}$ & $-0.0465 * * *$ & $0.0158 * * *$ & $-0.1236 * * *$ & 0.0016 & $-0.019 * * *$ & $-0.018^{* * *}$ \\
\hline & $\{.0000\}$ & $\{.2001\}$ & $\{.0000\}$ & $\{.0016\}$ & $\{.0000\}$ & $\{.0391\}$ & $\{.8460\}$ & $\{.0000\}$ & $\{.0000\}$ & $\{.0000\}$ & $\{.0000\}$ & $\{.5258\}$ & $\{.0006\}$ & $\{.0000\}$ \\
\hline \multirow[t]{2}{*}{ BANKCRED } & -0.0002 & $-0.0024 * * *$ & 0.0028 & $-0.0155^{* * *}$ & -0.0012 & -0.0031 & $0.0082 * * *$ & -0.0013 & $-0.0237 * * *$ & $-0.0063^{* *}$ & $-0.0608^{* * *}$ & $-0.0077 * * *$ & 0.0143* & $-0.0386 * * *$ \\
\hline & $\{.8583\}$ & $\{.0000\}$ & $\{.1884\}$ & $\{.0000\}$ & $\{.6713\}$ & $\{.3628\}$ & $\{.0001\}$ & $\{.4548\}$ & $\{.0015\}$ & $\{.0145\}$ & $\{.0000\}$ & $\{.0034\}$ & $\{.0543\}$ & $\{.0000\}$ \\
\hline \multirow[t]{2}{*}{ INTSPREAD } & $-0.0368 * * *$ & $-0.0015^{* *}$ & $-0.0839 * * *$ & $-0.0052 * *$ & 0.0187 & $-0.0457 * * *$ & 0.0038 & $-0.0242 * * *$ & $-0.1213 * *$ & -0.0057 & $-0.3313 * * *$ & $-0.024 * * *$ & $-0.31 * * *$ & $-0.0369 * * *$ \\
\hline & $\{.0000\}$ & $\{.0348\}$ & $\{.0000\}$ & $\{.0156\}$ & $\{.3368\}$ & $\{.0000\}$ & $\{.8102\}$ & $\{.0000\}$ & $\{.0298\}$ & $\{.1023\}$ & $\{.0000\}$ & $\{.0000\}$ & $\{.0000\}$ & $\{.0000\}$ \\
\hline \multirow[t]{2}{*}{ LIQTOASSET } & $0.0242 * * *$ & $0.0074 * * *$ & $0.0407 * * *$ & $0.0185^{* * *}$ & $0.0742 * * *$ & $0.0239 * *$ & $0.0296 * *$ & $0.0188^{* * *}$ & $0.1869 * * *$ & -0.0064 & $0.0996 * *$ & $0.0484^{* * *}$ & $0.28^{* * *}$ & $0.1141^{* * *}$ \\
\hline & $\{.0001\}$ & $\{.0000\}$ & $\{.0006\}$ & $\{.0001\}$ & $\{.0001\}$ & $\{.0157\}$ & $\{.0417\}$ & $\{.0011\}$ & $\{.0001\}$ & $\{.4782\}$ & $\{.0152\}$ & $\{.0000\}$ & $\{.0000\}$ & $\{.0000\}$ \\
\hline \multirow[t]{2}{*}{ RSINDEXCH } & $0.7224 *$ & $0.2601^{* *}$ & $1.83^{* * *}$ & -0.0512 & $2.643 * * *$ & -1.8445 & 0.7141 & 0.284 & $7.7486 * * *$ & -0.2596 & $6.5992 * * *$ & 0.2218 & 0.9915 & 0.9642 \\
\hline & $\{.0625\}$ & $\{.0349\}$ & $\{.0018\}$ & $\{.8567\}$ & $\{.0066\}$ & $\{.1283\}$ & $\{.3065\}$ & $\{.5747\}$ & $\{.0083\}$ & $\{.6334\}$ & $\{.0071\}$ & $\{.7464\}$ & $\{.4233\}$ & $\{.2512\}$ \\
\hline \multicolumn{15}{|c|}{ Panel E. Financial Openness } \\
\hline \multirow[t]{2}{*}{ FDI } & 0.0062 & $0.0145^{* * *}$ & -0.0269 & 0.0119 & $-0.0605^{* *}$ & $-0.0906^{* *}$ & -0.0064 & $-0.076^{* * *}$ & $-0.3452 * * *$ & -0.0158 & -0.0491 & 0.0036 & 0.0567 & $0.2546^{* * *}$ \\
\hline & $\{.5473\}$ & $\{.0028\}$ & $\{.1488\}$ & $\{.5276\}$ & $\{.0473\}$ & $\{.0230\}$ & $\{.7949\}$ & $\{.0001\}$ & $\{.0000\}$ & $\{.6245\}$ & $\{.4529\}$ & $\{.9109\}$ & $\{.3825\}$ & $\{.0000\}$ \\
\hline \multirow[t]{2}{*}{ PORTFOLIO } & 0.0000 & $-0.0001 * * *$ & $-0.0003 * * *$ & $-0.0003 * * *$ & $-0.0006 * * *$ & $-0.0006 * * *$ & $-0.0002 * * *$ & $-0.0003^{* * *}$ & $-0.0012 * * *$ & 0.0001 & $-0.0017 * * *$ & $-0.0007 * * *$ & $-0.0009 * * *$ & $-0.0008^{* * *}$ \\
\hline & $\{.1064\}$ & $\{.0000\}$ & $\{.0000\}$ & $\{.0000\}$ & $\{.0000\}$ & $\{.0000\}$ & $\{.0001\}$ & $\{.0000\}$ & $\{.0000\}$ & $\{.1245\}$ & $\{.0000\}$ & $\{.0000\}$ & $\{.0000\}$ & $\{.0000\}$ \\
\hline \multirow[t]{2}{*}{ DBARR } & -0.1397 & $0.1463 * * *$ & -0.2632 & -0.0455 & -0.1553 & $1.3601 * * *$ & $-0.4211 * *$ & 0.1864 & $3.9001 * * *$ & -0.0492 & $1.8389 * * *$ & 0.1797 & $-1.0717^{*}$ & $0.8645^{* * *}$ \\
\hline & $\{.1470\}$ & $\{.0000\}$ & $\{.1464\}$ & $\{.7184\}$ & $\{.5592\}$ & $\{.0000\}$ & $\{.0325\}$ & $\{.2140\}$ & $\{.0000\}$ & $\{.8032\}$ & $\{.0021\}$ & $\{.4236\}$ & $\{.0717\}$ & $\{.0026\}$ \\
\hline \multirow[t]{2}{*}{ FBARR } & -0.0181 & $-0.0701 * *$ & $0.6059 * * *$ & 0.0847 & $4.0039 * * *$ & $-1.1856 * * *$ & $0.7798^{* * *}$ & 0.2363 & $5.2513^{* * *}$ & -0.0399 & $2.1079 * * *$ & $-0.5406 * *$ & -0.222 & 0.3579 \\
\hline & $\{.8773\}$ & $\{.0397\}$ & $\{.0048\}$ & $\{.5053\}$ & $\{.0000\}$ & $\{.0000\}$ & $\{.0011\}$ & $\{.1329\}$ & $\{.0000\}$ & $\{.8446\}$ & $\{.0057\}$ & $\{.0190\}$ & $\{.7541\}$ & $\{.2772\}$ \\
\hline \multirow[t]{2}{*}{ FXREGM } & $-0.0805^{* *}$ & 0.0134 & $-0.9682 * * *$ & $0.1502^{* * *}$ & $-0.5801 * * *$ & 0.0662 & 0.0248 & $0.3556^{* * *}$ & $-2.3904 * * *$ & $-0.5136^{* * *}$ & $-1.9209 * * *$ & $0.4092 * * *$ & -0.0863 & $0.5673^{* * *}$ \\
\hline & $\{.0117\}$ & $\{.2131\}$ & $\{.0000\}$ & $\{.0001\}$ & $\{.0000\}$ & $\{.4390\}$ & $\{.7902\}$ & $\{.0000\}$ & $\{.0000\}$ & $\{.0000\}$ & $\{.0000\}$ & $\{.0000\}$ & $\{.6800\}$ & $\{.0000\}$ \\
\hline \multicolumn{15}{|c|}{ Panel F. Governance and Institutional Quality } \\
\hline \multirow[t]{2}{*}{ Gov } & -0.0223 & $-0.0427 * * *$ & $0.2335 * * *$ & $-0.0725 * * *$ & -0.029 & $0.1946 * * *$ & -0.0263 & $-0.1903 * * *$ & $-0.2423^{* *}$ & $-0.2033 * * *$ & $0.6656^{* * *}$ & $-0.2748 * * *$ & 0.0633 & $-0.4537 * * *$ \\
\hline & $\{.1635\}$ & $\{.0000\}$ & $\{.0000\}$ & $\{.0004\}$ & $\{.6021\}$ & $\{.0000\}$ & $\{.5274\}$ & $\{.0000\}$ & $\{.0400\}$ & $\{.0000\}$ & $\{.0000\}$ & $\{.0000\}$ & $\{.5316\}$ & $\{.0000\}$ \\
\hline Likelihood & -1899 & -614 & -2809 & -1690 & -3018 & -2556 & -1602 & -1305 & -4092 & -2071 & -3550 & -2216 & -4060 & -3124 \\
\hline Nobs & 1152 & 1078 & 1195 & 963 & 1120 & 986 & 771 & 725 & 1134 & 926 & 1036 & 890 & 1152 & 1078 \\
\hline
\end{tabular}


TABLE 3. Foreign Currency Ratings Spillover

\begin{tabular}{|c|c|c|c|c|c|c|c|}
\hline & Canada & France & Germany & Italy & Japan & UK & US \\
\hline \multicolumn{8}{|l|}{ Panel A. Asia Pacific } \\
\hline \multirow[t]{2}{*}{$\Delta$ CR_FC } & 0.0811 & 0.0448 & 0.5814 & 0.0303 & 1.609 & -0.529 & -0.0219 \\
\hline & $\{.3235\}$ & $\{.9281\}$ & $\{.2208\}$ & $\{.6816\}$ & $\{.2150\}$ & $\{.8385\}$ & $\{.9810\}$ \\
\hline \multirow[t]{2}{*}{$\Delta$ Outlook_FC } & 0.503 & -0.5319 & 2.9036 & 0.3455 & 3.862 & -1.5745 & -0.6326 \\
\hline & $\{.3604\}$ & $\{.8733\}$ & $\{.3607\}$ & $\{.4858\}$ & $\{.6568\}$ & $\{.9276\}$ & $\{.9183\}$ \\
\hline \multicolumn{8}{|l|}{ Spillover from Asia Pacific } \\
\hline \multirow[t]{2}{*}{ Spillover from Latin America } & $-3.3973 * * *$ & $-27.8167 * * *$ & $-31.5102 * * *$ & $-2.8041 * * *$ & $-56.7639 * * *$ & $-99.2615^{* * *}$ & $-45.674 * * *$ \\
\hline & $\{.0000\}$ & $\{.0000\}$ & $\{.0000\}$ & $\{.0000\}$ & $\{.0000\}$ & $\{.0000\}$ & $\{.0000\}$ \\
\hline \multirow[t]{2}{*}{ Spillover from Africa and Middle East } & -0.5945 & $-8.2903 * * *$ & $-8.9351 * * *$ & $-0.69 *$ & $-17.2402 * * *$ & $-35.6302 * * *$ & $-18.3745^{* * *}$ \\
\hline & $\{.1249\}$ & $\{.0069\}$ & $\{.0001\}$ & $\{.0758\}$ & $\{.0084\}$ & $\{.0011\}$ & $\{.0012\}$ \\
\hline \multirow[t]{2}{*}{ Spillover from Eastern Europe } & -0.3941 & $-7.0032 * * *$ & $-3.8133 * *$ & -0.4897 & -5.2152 & $-22.486 * *$ & $-14.8989 * * *$ \\
\hline & $\{.2193\}$ & $\{.0062\}$ & $\{.0381\}$ & $\{.1291\}$ & $\{.3363\}$ & $\{.0124\}$ & $\{.0017\}$ \\
\hline \multirow[t]{2}{*}{ Principal Component } & 0 & $-0.0003 * * *$ & $0.0002 * *$ & 0 & $0.0008 * * *$ & $-0.0034 * * *$ & $-0.0006 * * *$ \\
\hline & $\{.6918\}$ & $\{.0007\}$ & $\{.0330\}$ & $\{.4367\}$ & $\{.0022\}$ & $\{.0000\}$ & $\{.0003\}$ \\
\hline Nobs & 594 & 594 & 594 & 594 & 594 & 594 & 594 \\
\hline \multicolumn{8}{|l|}{ Panel B. Latin America } \\
\hline \multirow[t]{2}{*}{$\Delta \mathrm{CR} \_\mathrm{FC}$} & -0.0288 & -0.4387 & -0.5829 & 0.0193 & $-0.3951 * * *$ & -0.0834 & -0.5872 \\
\hline & $\{.3853\}$ & $\{.3676\}$ & $\{.2124\}$ & $\{.7179\}$ & $\{.0092\}$ & $\{.9694\}$ & $\{.1197\}$ \\
\hline \multirow[t]{2}{*}{$\Delta$ Outlook_FC } & -0.1066 & -0.6398 & -0.3596 & 0.1084 & -0.3448 & 1.6362 & -1.3451 \\
\hline & $\{.3791\}$ & $\{.7170\}$ & $\{.8329\}$ & $\{.5783\}$ & $\{.5323\}$ & $\{.8357\}$ & $\{.3313\}$ \\
\hline \multirow[t]{2}{*}{ Spillover from Asia Pacific } & 0.0421 & 0.3498 & 0.4557 & $0.1073 * *$ & 0.1444 & -1.3382 & 0.255 \\
\hline & $\{.1052\}$ & $\{.4895\}$ & $\{.2611\}$ & $\{.0160\}$ & $\{.3019\}$ & $\{.5473\}$ & $\{.3662\}$ \\
\hline \multicolumn{8}{|l|}{ Spillover from Latin America } \\
\hline \multirow[t]{2}{*}{ Spillover from Africa and Middle East } & 0.0158 & $-4.5525 * * *$ & $-5.7312 * * *$ & $-0.3819 * * *$ & $-0.9897 * * *$ & -5.4778 & $-3.2368 * * *$ \\
\hline & $\{.7887\}$ & $\{.0001\}$ & $\{.0000\}$ & $\{.0002\}$ & $\{.0018\}$ & $\{.2763\}$ & $\{.0000\}$ \\
\hline \multirow[t]{2}{*}{ Spillover from Eastern Europe } & -0.0476 & $-2.2842 * *$ & -0.9343 & -0.1212 & -0.2532 & -6.0126 & -0.6882 \\
\hline & $\{.3334\}$ & $\{.0169\}$ & $\{.2232\}$ & $\{.1504\}$ & $\{.3381\}$ & $\{.1524\}$ & $\{.1979\}$ \\
\hline \multirow[t]{2}{*}{ Principal Component } & $0.0001^{* * *}$ & $0.0004 * * *$ & $0.0015^{* * *}$ & $0 * * *$ & $0.0006 * * *$ & $0.0105^{* * *}$ & $0.0014 * * *$ \\
\hline & $\{.0000\}$ & $\{.0002\}$ & $\{.0000\}$ & $\{.0004\}$ & $\{.0000\}$ & $\{.0000\}$ & $\{.0000\}$ \\
\hline Nobs & 432 & 432 & 432 & 432 & 432 & 432 & 432 \\
\hline
\end{tabular}


Note: This table presents the regional rating spillover effects of foreign-currency-denominated sovereign ratings of Eq (2A) below. G7BankFlows $s_{i, t}^{j}=$

$\alpha+\beta_{1} \cdot \Delta C R_{i, t-1}+\beta_{2} \cdot \Delta$ Outlook $_{i, t-1}+\beta_{3} \cdot \Delta C R_{-}$Spillover_ $1_{t-1}+\beta_{4} \cdot \Delta C R_{-}$Spillover_ $_{t-1}+\beta_{5} \cdot \Delta C R_{-}$Spillover_ $_{t-1}+\beta_{6} \cdot$ Principal_Component $_{t}$

Where G7BankFlows are the quarterly changes in the foreign claims of G7 countries' banks against 55 emerging market countries. CR and Outlook are sovereign credit ratings and outlooks of the emerging market countries' debt denominated in foreign currencies. $\Delta \mathrm{CR} \_$Spillover_1, $\Delta \mathrm{CR} \_$Spillover_2 and $\Delta \mathrm{CR} \_$Spillover_3 are the average foreign currency rating changes of the other three regions. The control variables incorporate country-specific variables. Numbers in braces are $p$-values.

$* * *$ Significant at the $1 \%$ level.

** Significant at the $5 \%$ level.

*Significant at the $10 \%$ level. 
TABLE 3. - Continued

\begin{tabular}{|c|c|c|c|c|c|c|c|}
\hline & Canada & France & Germany & Italy & Japan & UK & US \\
\hline \multicolumn{8}{|l|}{ Panel C. Africa and Middle East } \\
\hline \multirow[t]{2}{*}{$\overline{\Delta \mathrm{CR} \_\mathrm{FC}}$} & 0.0044 & 0.2855 & -0.0547 & -0.1742 & -0.16 & 0.1246 & -0.3359 \\
\hline & $\{.6878\}$ & $\{.5659\}$ & $\{.9546\}$ & $\{.7984\}$ & $\{.2047\}$ & $\{.1975\}$ & $\{.2464\}$ \\
\hline \multirow[t]{2}{*}{$\Delta$ Outlook_FC } & 0.0073 & -0.7558 & -0.9563 & -3.3698 & -0.7261 & -0.0624 & -0.6198 \\
\hline & $\{.8727\}$ & $\{.7117\}$ & $\{.8099\}$ & $\{.2296\}$ & $\{.1645\}$ & $\{.8764\}$ & $\{.6053\}$ \\
\hline \multirow[t]{2}{*}{ Spillover from Asia Pacific } & $0.0261^{*}$ & -0.1578 & -0.128 & -0.7682 & 0.1558 & 0.128 & 0.3182 \\
\hline & $\{.0920\}$ & $\{.9201\}$ & $\{.9458\}$ & $\{.7030\}$ & $\{.5089\}$ & $\{.4385\}$ & $\{.5637\}$ \\
\hline \multirow[t]{2}{*}{ Spillover from Latin America } & $-0.0844 *$ & $-14.2971 * * *$ & $-38.4632 * * *$ & $-17.4406 * * *$ & $-2.4428 * * *$ & $-2.1817 * * *$ & $-8.2545 * * *$ \\
\hline & $\{.0766\}$ & $\{.0032\}$ & $\{.0000\}$ & $\{.0050\}$ & $\{.0008\}$ & $\{.0000\}$ & $\{.0000\}$ \\
\hline \multicolumn{8}{|l|}{ Spillover from Africa and Middle East } \\
\hline \multirow[t]{2}{*}{ Spillover from Eastern Europe } & -0.0497 & $-5.6837^{*}$ & $-6.5656^{*}$ & -6.2118 & $-1.0462 * *$ & 0.0958 & -1.7793 \\
\hline & $\{.1091\}$ & $\{.0728\}$ & $\{.0824\}$ & $\{.1254\}$ & $\{.0272\}$ & $\{.7727\}$ & $\{.1080\}$ \\
\hline \multirow[t]{2}{*}{ Principal Component } & $0 * * *$ & $0.0004 * * *$ & $0.003 * * *$ & 0.0001 & $0.0002 * * *$ & $0.0001^{* *}$ & $0.0009 * * *$ \\
\hline & $\{.0000\}$ & $\{.0037\}$ & $\{.0000\}$ & $\{.5458\}$ & $\{.0000\}$ & $\{.0187\}$ & $\{.0000\}$ \\
\hline Nobs & 864 & 864 & 864 & 864 & 864 & 864 & 864 \\
\hline \multicolumn{8}{|l|}{ Panel D. Eastern Europe } \\
\hline \multirow[t]{2}{*}{$\Delta \mathrm{CR} \_\mathrm{FC}$} & -0.032 & 0.1603 & 0.3112 & 0.1125 & $0.3414^{*}$ & 0.3113 & 1.0526 \\
\hline & $\{.7498\}$ & $\{.2264\}$ & $\{.1143\}$ & $\{.3846\}$ & $\{.0812\}$ & $\{.2597\}$ & $\{.1898\}$ \\
\hline \multirow[t]{2}{*}{$\Delta$ Outlook_FC } & 0.3946 & $1.6166 * *$ & $4.387 * * *$ & 0.6556 & $5.8429 * * *$ & 1.8706 & $11.2057 * *$ \\
\hline & $\{.5008\}$ & $\{.0402\}$ & $\{.0002\}$ & $\{.3854\}$ & $\{.0000\}$ & $\{.2464\}$ & $\{.0204\}$ \\
\hline \multirow[t]{2}{*}{ Spillover from Asia Pacific } & $0.522 * * *$ & $0.6044 * * *$ & $0.8644 * * *$ & $0.4627^{*}$ & $0.4112 * * *$ & 0.4536 & $1.5812 *$ \\
\hline & $\{.0050\}$ & $\{.0003\}$ & $\{.0001\}$ & $\{.0637\}$ & $\{.0026\}$ & $\{.3793\}$ & $\{.0692\}$ \\
\hline \multirow[t]{2}{*}{ Spillover from Latin America } & $-2.1417 * * *$ & $-4.7005^{* * *}$ & $-9.009 * * *$ & $-4.0515^{* * *}$ & $-5.3283 * * *$ & $-4.6828 * * *$ & $-21.9978 * * *$ \\
\hline & $\{.0002\}$ & $\{.0000\}$ & $\{.0000\}$ & $\{.0000\}$ & $\{.0000\}$ & $\{.0032\}$ & $\{.0000\}$ \\
\hline \multirow[t]{2}{*}{ Spillover from Africa and Middle East } & $-0.7451 *$ & $-2.0746 * * *$ & $-3.9566 * * *$ & $-1.4427 * *$ & $-2.7036 * * *$ & $-2.5252 * *$ & $-12.9322 * * *$ \\
\hline & $\{.0949\}$ & $\{.0000\}$ & $\{.0000\}$ & $\{.0161\}$ & $\{.0000\}$ & $\{.0416\}$ & $\{.0000\}$ \\
\hline \multicolumn{8}{|l|}{ Spillover from Eastern Europe } \\
\hline \multirow[t]{2}{*}{ Principal Component } & $0.0002 * * *$ & $0.0012 * * *$ & $0.0011^{* * *}$ & $0.0004^{* * *}$ & $0.0015^{* * *}$ & $0.0024 * * *$ & $0.005^{* * *}$ \\
\hline & $\{.0000\}$ & $\{.0000\}$ & $\{.0000\}$ & $\{.0000\}$ & $\{.0000\}$ & $\{.0000\}$ & $\{.0000\}$ \\
\hline Nobs & 1080 & 1080 & 1080 & 1080 & 1080 & 1080 & 1080 \\
\hline
\end{tabular}


TABLE 4. Local Currency Ratings Spillover

\begin{tabular}{|c|c|c|c|c|c|c|c|}
\hline & Canada & France & Germany & Italy & Japan & UK & US \\
\hline \multicolumn{8}{|l|}{ Panel A. Asia Pacific } \\
\hline \multirow[t]{2}{*}{$\Delta$ CR_LC } & 0.1289 & 0.1986 & 0.8072 & 0.0208 & 2.6273 & -0.6875 & 0.2734 \\
\hline & $\{.2405\}$ & $\{.7675\}$ & $\{.2024\}$ & $\{.8343\}$ & $\{.1296\}$ & $\{.8411\}$ & $\{.8259\}$ \\
\hline \multirow[t]{2}{*}{$\Delta$ Outlook_LC } & 0.5841 & -1.2246 & 4.4467 & 0.3471 & 1.8998 & 4.6064 & -0.3493 \\
\hline & $\{.3534\}$ & $\{.7436\}$ & $\{.2211\}$ & $\{.5368\}$ & $\{.8473\}$ & $\{.8181\}$ & $\{.9598\}$ \\
\hline \multicolumn{8}{|l|}{ Spillover from Asia Pacific } \\
\hline \multirow[t]{2}{*}{ Spillover from Latin America } & $-3.786 * * *$ & $-35.2475 * * *$ & $-36.8745 * * *$ & $-3.191 * * *$ & $-54.7206 * * *$ & $-127.3794 * * *$ & $-63.0746 * * *$ \\
\hline & $\{.0000\}$ & $\{.0000\}$ & $\{.0000\}$ & $\{.0001\}$ & $\{.0001\}$ & $\{.0000\}$ & $\{.0000\}$ \\
\hline \multirow[t]{2}{*}{ Spillover from Africa and Middle East } & 0.1452 & -4.0694 & -4.4186 & -0.069 & -3.049 & $-29.1391 *$ & $-13.6591 *$ \\
\hline & $\{.7954\}$ & $\{.3586\}$ & $\{.1665\}$ & $\{.9023\}$ & $\{.7427\}$ & $\{.0614\}$ & $\{.0965\}$ \\
\hline \multirow[t]{2}{*}{ Spillover from Eastern Europe } & 0.1461 & -1.0125 & 1.9055 & -0.0313 & 3.1634 & -1.4982 & -4.4627 \\
\hline & $\{.6283\}$ & $\{.6723\}$ & $\{.2683\}$ & $\{.9178\}$ & $\{.5276\}$ & $\{.8582\}$ & $\{.3145\}$ \\
\hline \multirow[t]{2}{*}{ Principal Component } & 0.0000 & $-0.0003^{* * *}$ & $0.0002^{* *}$ & 0.0000 & $0.0007 * * *$ & $-0.0034 * * *$ & $-0.0006 * * *$ \\
\hline & $\{.7759\}$ & $\{.0006\}$ & $\{.0494\}$ & $\{.4805\}$ & $\{.0033\}$ & $\{.0000\}$ & $\{.0002\}$ \\
\hline Nobs & 594 & 594 & 594 & 594 & 594 & 594 & 594 \\
\hline \multicolumn{8}{|l|}{ Panel B. Latin America } \\
\hline \multirow[t]{2}{*}{$\Delta \mathrm{CR} \_\mathrm{LC}$} & -0.0393 & -0.5229 & -0.2793 & $0.1115^{*}$ & $-0.572 * * *$ & -2.401 & $-0.9073 * *$ \\
\hline & $\{.3296\}$ & $\{.3703\}$ & $\{.6214\}$ & $\{.0844\}$ & $\{.0017\}$ & $\{.3572\}$ & $\{.0489\}$ \\
\hline \multirow[t]{2}{*}{$\Delta$ Outlook_LC } & 0.0426 & 0.0112 & 0.7527 & 0.3002 & -0.1495 & -0.1791 & -0.7881 \\
\hline & $\{.7669\}$ & $\{.9957\}$ & $\{.7093\}$ & $\{.1929\}$ & $\{.8183\}$ & $\{.9847\}$ & $\{.6303\}$ \\
\hline \multirow[t]{2}{*}{ Spillover from Asia Pacific } & 0.0338 & 0.1208 & 0.3744 & $0.1001^{*}$ & 0.1485 & -2.0792 & 0.1829 \\
\hline & $\{.2622\}$ & $\{.8386\}$ & $\{.4294\}$ & $\{.0597\}$ & $\{.3611\}$ & $\{.4217\}$ & $\{.5753\}$ \\
\hline \multicolumn{8}{|l|}{ Spillover from Latin America } \\
\hline \multirow[t]{2}{*}{ Spillover from Africa and Middle East } & 0.1252 & -2.7872 & $-4.2949 * * *$ & -0.1459 & -0.5934 & -3.9417 & $-2.7074 * * *$ \\
\hline & $\{.1461\}$ & $\{.1001\}$ & $\{.0015\}$ & $\{.3368\}$ & $\{.2017\}$ & $\{.5940\}$ & $\{.0037\}$ \\
\hline \multirow[t]{2}{*}{ Spillover from Eastern Europe } & -0.051 & -0.6923 & 0.6663 & 0.011 & -0.0641 & $-7.0034^{*}$ & 0.1136 \\
\hline & $\{.2635\}$ & $\{.4401\}$ & $\{.3524\}$ & $\{.8910\}$ & $\{.7944\}$ & $\{.0734\}$ & $\{.8180\}$ \\
\hline \multirow[t]{2}{*}{ Principal Component } & $0.0001 * * *$ & $0.0004 * * *$ & $0.0016 * * *$ & $0.0000 * * *$ & $0.0006 * * *$ & $0.0105 * * *$ & $0.0015^{* * *}$ \\
\hline & $\{.0000\}$ & $\{.0001\}$ & $\{.0000\}$ & $\{.0002\}$ & $\{.0000\}$ & $\{.0000\}$ & $\{.0000\}$ \\
\hline Nobs & 432 & 432 & 432 & 432 & 432 & 432 & 432 \\
\hline
\end{tabular}


Note: This table presents the regional ratings spillover effects of local-currency-denominated sovereign ratings of Eq (2B) below. G7BankFlows $s_{i, t}^{j}=$

$\alpha+\beta_{1} \cdot \Delta C R_{i, t-1}+\beta_{2} \cdot \Delta O$ utlook $_{i, t-1}+\beta_{3} \cdot \Delta C R_{-}$Spillover_1 $1_{t-1}+\beta_{4} \cdot \Delta C R_{-}$Spillover_2 ${ }_{t-1}+\beta_{5} \cdot \Delta C R_{-}$Spillover_3 $3_{t-1}+\beta_{6} \cdot$ Principal_Component $t_{t}$

Where G7BankFlows are the quarterly changes in foreign claims of G7 countries' banks against 55 emerging market countries. CR and Outlook are sovereign credit ratings and outlooks of the emerging market countries debt denominated in local currencies. $\Delta$ CR_Spillover_1, $\Delta$ CR_Spillover_2 and $\Delta$ CR_Spillover_3 are average local currency rating changes of the other three regions. The control variables incorporate country-specific variables. Numbers in braces are $p$-values.

*** Significant at the $1 \%$ level.

$* *$ Significant at the $5 \%$ level.

*Significant at the $10 \%$ level. 
TABLE 4. - Continued

\begin{tabular}{|c|c|c|c|c|c|c|c|}
\hline & Canada & France & Germany & Italy & Japan & UK & US \\
\hline \multicolumn{8}{|l|}{ Panel C. Africa and Middle East } \\
\hline \multirow[t]{2}{*}{$\Delta \mathrm{CR} \_L C$} & 0.0023 & -0.2032 & $-2.442 * *$ & 0.0051 & $-0.3039 *$ & 0.1178 & $-0.8258 * *$ \\
\hline & $\{.8633\}$ & $\{.7391\}$ & $\{.0385\}$ & $\{.9951\}$ & $\{.0501\}$ & $\{.3235\}$ & $\{.0203\}$ \\
\hline \multirow[t]{2}{*}{$\Delta$ Outlook_LC } & 0.0147 & -0.0205 & 0.5178 & -0.9829 & -0.441 & -0.0382 & -0.0313 \\
\hline & $\{.7631\}$ & $\{.9926\}$ & $\{.9036\}$ & $\{.7454\}$ & $\{.4328\}$ & $\{.9297\}$ & $\{.9807\}$ \\
\hline Spillover from Asia Pacific & $0.0332 *$ & 0.1491 & 1.4368 & -0.5506 & 0.242 & 0.2117 & 0.6685 \\
\hline Spillover from Latin America & $\{.0793\}$ & $\{.0109\}$ & $\{.0000\}$ & $\{.0141\}$ & $\{.0056\}$ & $\{.0146\}$ & $\{.0001\}$ \\
\hline \multicolumn{8}{|l|}{ Spillover from Africa and Middle East } \\
\hline Spillover from Eastern Europe & -0.036 & -3.5809 & -2.2489 & -4.424 & -0.6206 & 0.2322 & -0.7318 \\
\hline \multicolumn{8}{|l|}{ Panel D. Eastern Europe } \\
\hline \multirow[t]{2}{*}{$\Delta \mathrm{CR} \_L C$} & 0.0046 & $0.287 * * *$ & $0.7388^{* * *}$ & $0.1978 *$ & $1.0261^{* * *}$ & 0.3069 & $1.9999 * * *$ \\
\hline & $\{.9556\}$ & $\{.0098\}$ & $\{.0000\}$ & $\{.0658\}$ & $\{.0000\}$ & $\{.1816\}$ & $\{.0031\}$ \\
\hline \multirow[t]{2}{*}{$\Delta$ Outlook_LC } & 0.6764 & $2.0141^{* *}$ & $4.5515^{* * *}$ & 0.9796 & $4.7725^{* * *}$ & 2.8125 & $12.4444 * *$ \\
\hline & $\{.3072\}$ & $\{.0236\}$ & $\{.0006\}$ & $\{.2511\}$ & $\{.0007\}$ & $\{.1232\}$ & $\{.0227\}$ \\
\hline \multirow[t]{2}{*}{ Spillover from Asia Pacific } & $0.5109 * *$ & $0.8031^{* * *}$ & $1.1511^{* * *}$ & $0.6245^{* *}$ & $0.5745^{* * *}$ & 0.742 & $2.0298 * *$ \\
\hline & $\{.0174\}$ & $\{.0000\}$ & $\{.0000\}$ & $\{.0318\}$ & $\{.0003\}$ & $\{.2181\}$ & $\{.0467\}$ \\
\hline \multirow[t]{2}{*}{ Spillover from Latin America } & -1.306 & $-5.1762 * * *$ & $-9.7024 * * *$ & $-3.1944 * * *$ & $-5.201 * * *$ & $-6.1053 * *$ & $-21.3273 * * *$ \\
\hline & $\{.1387\}$ & $\{.0000\}$ & $\{.0000\}$ & $\{.0075\}$ & $\{.0000\}$ & $\{.0136\}$ & $\{.0000\}$ \\
\hline \multirow[t]{2}{*}{ Spillover from Africa and Middle East } & 0.146 & $-1.6079 * * *$ & $-3.1344 * * *$ & -0.9321 & $-2.3509 * * *$ & -2.6133 & $-12.4069 * * *$ \\
\hline & $\{.8093\}$ & $\{.0038\}$ & $\{.0000\}$ & $\{.2550\}$ & $\{.0000\}$ & $\{.1235\}$ & $\{.0000\}$ \\
\hline
\end{tabular}


TABLE 5. Sub-sample Analysis of Foreign Currency Spillover Effects: 1995-2003 and 2004-2008

\begin{tabular}{|c|c|c|c|c|c|c|c|c|c|c|c|c|c|c|}
\hline & \multicolumn{7}{|c|}{1995 to 2003} & \multicolumn{7}{|c|}{$2004-2008$} \\
\hline & Canada & France & Germany & Italy & Japan & UK & US & Canada & France & Germany & Italy & Japan & UK & US \\
\hline \multicolumn{15}{|l|}{ Panel A. Asia Pacific } \\
\hline \multirow[t]{2}{*}{$\begin{array}{l}\text { Spillover from Latin America } \\
\text {. }\end{array}$} & $-2.3291 * * *$ & $-16.6787 * * *$ & $-21.8614 * * *$ & $-1.9264 * * *$ & $-46.1828 * * *$ & $-59.8286 * * *$ & $-26.6911 * * *$ & $-5.7782 * * *$ & $-51.3016 * * *$ & $-49.7027 * * *$ & $-4.9175^{* *}$ & $-62.1031^{* * *}$ & $179.7099 * * *$ & $-89.9621 * * *$ \\
\hline & $\{.0000\}$ & $\{.0000\}$ & $\{.0000\}$ & $\{.0000\}$ & $\{.0000\}$ & $\{.0000\}$ & $\{.0000\}$ & $\{.0085\}$ & $\{.0012\}$ & $\{.0000\}$ & $\{.0140\}$ & $\{.0015\}$ & $\{.0017\}$ & $\{.0001\}$ \\
\hline \multirow[t]{2}{*}{ Spillover from Africa and Middle Eas } & -0.132 & $-3.3364 * * *$ & -2.0863 & $-0.4648^{*}$ & -10.7735 & $-12.7205^{* * *}$ & $-4.5137 * * *$ & -0.0886 & -7.0024 & -11.4028 & -0.4318 & -14.4832 & -33.2309 & $-24.5426 *$ \\
\hline & $\{.6525\}$ & $\{.0000\}$ & $\{.1791\}$ & $\{.0609\}$ & $\{.1376\}$ & $\{.0021\}$ & $\{.0014\}$ & $\{.9457\}$ & $\{.4572\}$ & $\{.1118\}$ & $\{.7153\}$ & $\{.2112\}$ & $\{.3311\}$ & $\{.0693\}$ \\
\hline \multirow[t]{2}{*}{ Spillover from Eastern Europe } & $1.5553^{* * *}$ & $12.9656^{* * *}$ & $15.4984^{* * *}$ & $1.0295^{* * *}$ & $22.37^{* * *}$ & $51.6235^{* * *}$ & $20.2972^{* * *}$ & -0.7886 & $-12.2228^{* *}$ & $-8.9832 * *$ & -0.8789 & $-14.576 * *$ & $-41.4742^{* *}$ & $-23.7132 * * *$ \\
\hline & $\{.0000\}$ & $\{.0000\}$ & $\{.0000\}$ & $\{.0001\}$ & $\{.0039\}$ & $\{.0000\}$ & $\{.0000\}$ & $\{.3010\}$ & $\{.0269\}$ & $\{.0327\}$ & $\{.2070\}$ & $\{.0319\}$ & $\{.0366\}$ & $\{.0024\}$ \\
\hline Nobs & 374 & 374 & 374 & 374 & 374 & 374 & 374 & 220 & 220 & 220 & 220 & 220 & 220 & 220 \\
\hline \multicolumn{15}{|l|}{ Panel B. Latin America } \\
\hline \multirow[t]{2}{*}{ Spillover from Asia Pacific } & $0.0394 *$ & $0.3666 * * *$ & $0.5028^{*}$ & $0.0688 * * *$ & $0.1587^{* * * *}$ & 0.2337 & $0.3553^{* *}$ & -0.0468 & -3.41 & -2.8838 & -0.0138 & 0.1795 & 7.447 & -0.9884 \\
\hline & $\{.0541\}$ & $\{.0091\}$ & $\{.0969\}$ & $\{.0000\}$ & $\{.0021\}$ & $\{.1530\}$ & $\{.0241\}$ & $\{.7547\}$ & $\{.1455\}$ & $\{.1403\}$ & $\{.9642\}$ & $\{.8449\}$ & $\{.5591\}$ & $\{.4704\}$ \\
\hline \multirow[t]{2}{*}{ Spillover from Africa and Middle Eas } & 0.0441 & $-1.5682 * * *$ & $-2.5964 * * *$ & $-0.2479 * * *$ & $-0.5724 * * *$ & $-1.5808 * * *$ & $-1.3223 * * *$ & 0.1005 & $-5.3137 * *$ & $-6.5187 * * *$ & $-0.545 *$ & -0.6043 & 7.721 & $-3.0859 * *$ \\
\hline & $\{.4213\}$ & $\{.0000\}$ & $\{.0014\}$ & $\{.0000\}$ & $\{.0000\}$ & $\{.0003\}$ & $\{.0019\}$ & $\{.5323\}$ & $\{.0349\}$ & $\{.0019\}$ & $\{.0982\}$ & $\{.5399\}$ & $\{.5731\}$ & $\{.0362\}$ \\
\hline Spillover from Eastern Europe & $\begin{array}{l}0.1437 * * \\
\{.0124\}\end{array}$ & $\begin{array}{l}3.0114 * * * \\
\{.0000\}\end{array}$ & $\begin{array}{l}5.0114^{* * *} \\
\{.0000\}\end{array}$ & $\begin{array}{l}0.2488^{* * *} \\
\{.0000\}\end{array}$ & $\begin{array}{l}0.8718^{* * *} \\
\{.0000\}\end{array}$ & $\begin{array}{l}3.1071^{* * *} \\
\{.0000\}\end{array}$ & $\begin{array}{l}2.5186^{* * * *} \\
\{.0000\}\end{array}$ & $\begin{array}{l}-0.1756 * * \\
\{.0444\}\end{array}$ & $\begin{array}{l}-4.809 * * * \\
\{.0004\}\end{array}$ & $\begin{array}{l}-4.4741^{* * *} \\
\{.0001\}\end{array}$ & $\begin{array}{l}-0.3992 * * \\
\{.0260\}\end{array}$ & $\begin{array}{l}-1.1719 * * \\
\{.0290\}\end{array}$ & $\begin{array}{l}-15.6908^{* *} \\
\{.0352\}\end{array}$ & $\begin{array}{l}-2.7002 * * * \\
\{.0007\}\end{array}$ \\
\hline Nobs & 272 & 272 & 272 & 272 & 272 & 272 & 272 & 160 & 160 & 160 & 160 & 160 & 160 & 160 \\
\hline \multicolumn{15}{|l|}{ Panel C. Africa and Middle East } \\
\hline \multirow[t]{2}{*}{$\begin{array}{l}\text { Spillover from Asia Pacific } \\
\end{array}$} & $0.0285^{* * *}$ & $0.4574 * *$ & $1.68^{* *}$ & -0.2489 & $0.2258^{* * *}$ & 0.174 & $0.664^{* * *}$ & 0.1544 & 0.7855 & -9.8133 & 0.5053 & 1.1638 & 0.0836 & -0.2424 \\
\hline & $\{.0003\}$ & $\{.0172\}$ & $\{.0241\}$ & $\{.5987\}$ & $\{.0000\}$ & $\{.1184\}$ & $\{.0014\}$ & $\{.1426\}$ & $\{.9224\}$ & $\{.2474\}$ & $\{.9603\}$ & $\{.4584\}$ & $\{.9387\}$ & $\{.9368\}$ \\
\hline \multirow[t]{2}{*}{ Spillover from Latin America } & -0.0325 & $-4.844 * * *$ & $-21.4355^{* * *}$ & $-6.5001^{* * *}$ & $-1.2033^{* * *}$ & $-1.7414 * * *$ & $-4.3119 * * *$ & $-0.3152 *$ & $-41.3609^{* * *}$ & $-68.0814 * * *$ & $-49.1681^{* * *}$ & $-5.7066 * *$ & -2.2025 & $-17.0349 * * *$ \\
\hline & $\{.2217\}$ & $\{.0000\}$ & $\{.0000\}$ & $\{.0000\}$ & $\{.0000\}$ & $\{.0000\}$ & $\{.0000\}$ & $\{.0955\}$ & $\{.0047\}$ & $\{.0000\}$ & $\{.0076\}$ & $\{.0443\}$ & $\{.2620\}$ & $\{.0020\}$ \\
\hline \multirow[t]{2}{*}{ Spillover from Eastern Europe } & 0.0188 & $4.5338^{* * *}$ & $17.5319 * * *$ & $5.4279 * * *$ & $0.6098^{* * *}$ & $1.2987 * * *$ & $3.3976^{* * *}$ & -0.0811 & -8.5157 & $-16.3745^{* * *}$ & -9.3896 & -1.6933 & -0.7906 & $-3.6053^{*}$ \\
\hline & $\{.4125\}$ & $\{.0000\}$ & $\{.0000\}$ & $\{.0001\}$ & $\{.0000\}$ & $\{.0001\}$ & $\{.0000\}$ & $\{.2435\}$ & $\{.1149\}$ & $\{.0036\}$ & $\{.1673\}$ & $\{.1058\}$ & $\{.2752\}$ & $\{.0759\}$ \\
\hline Nobs & 544 & 544 & 544 & 544 & 544 & 544 & 544 & 320 & 320 & 320 & 320 & 320 & 320 & 320 \\
\hline \multicolumn{15}{|l|}{ Panel D. Eastern Europe } \\
\hline \multirow[t]{2}{*}{ Spillover from Asia Pacific } & $0.4523^{* *}$ & $0.616^{* * *}$ & $0.9425 * * *$ & 0.2514 & $0.3095 * * *$ & $0.8078^{* *}$ & $2.2006 *$ & -0.2641 & $-2.1934 * *$ & $-4.8178^{* * *}$ & $-1.2228 * * *$ & $-3.2184 * * *$ & -2.5561 & $-17.8947 * * *$ \\
\hline & $\{.0100\}$ & $\{.0012\}$ & $\{.0056\}$ & $\{.3387\}$ & $\{.0015\}$ & $\{.0494\}$ & $\{.0574\}$ & $\{.2767\}$ & $\{.0283\}$ & $\{.0000\}$ & $\{.0053\}$ & $\{.0011\}$ & $\{.2850\}$ & $\{.0000\}$ \\
\hline \multirow[t]{2}{*}{ Spillover from Latin America } & $-2.2241 * * *$ & $-3.9187 * * *$ & $-7.6524 * * *$ & $-4.1688 * * *$ & $-4.5805^{* * *}$ & $-5.0522 * * *$ & $-19.656^{* * *}$ & $-0.8404 * *$ & $-5.0318^{* * *}$ & $-7.7381^{* * *}$ & -0.6285 & $-4.7204 * * *$ & 0.373 & 3.6381 \\
\hline & 0.00011262 & 0 & 0 & 0.00000135 & 0 & 0.00018372 & 0.00000023 & 0.04415907 & 0.0031428 & 0.00000103 & 0.39838275 & 0.00699476 & 0.92705284 & 0.28221834 \\
\hline Spillover from Africa and Middle Eas & -0.756 & $-0.8644 *$ & $-1.6197 *$ & -0.8406 & $\begin{array}{l}-0.7711^{* * *} \\
\{0052\}\end{array}$ & $\begin{array}{l}-0.8978 \\
\{4172\}\end{array}$ & $\begin{array}{l}-6.8866 * * \\
\text { fo273\} }\end{array}$ & $-0.4657 *$ & $\begin{array}{l}-2.9045^{* *} \\
\{0109\}\end{array}$ & $-6.114 * * *$ & $-2.1675^{* * *}$ & $-3.7231 * * *$ & $-6.0738^{* *}$ & $-21.1842 * * *$ \\
\hline Nobs & 680 & 680 & 680 & 680 & 680 & 680 & 680 & 400 & 400 & 400 & 400 & 400 & 400 & 400 \\
\hline
\end{tabular}

Note: This table presents the estimated regional rating spillover coefficients for foreign-currency-denominated sovereign rating revisions in emerging market regions over two sub-samples: Q1: 1995 - Q4: 2003 and Q1: 2004 - Q4: 2008 (from Eq. (2A). Numbers in braces are pvalues.

$* * *$ Significant at the $1 \%$ level.

$* *$ Significant at the $5 \%$ level.

*Significant at the $10 \%$ level. 